Article

\title{
Understanding Stress Response to High-Arsenic Gold-Bearing Sulfide Concentrate in Extremely Metal-Resistant Acidophile Sulfobacillus thermotolerans
}

\author{
Anna Panyushkina $1, * \mathbb{D}$, Daria Matyushkina ${ }^{2} \mathbb{D}$ and Olga Pobeguts ${ }^{2}$ \\ 1 Winogradsky Institute of Microbiology, Research Centre of Biotechnology of the Russian Academy of \\ Sciences, Leninsky Ave., 33, bld. 2, Moscow 119071, Russia \\ 2 Federal Research and Clinical Center of Physical-Chemical Medicine of Federal Medical Biological Agency, \\ Malaya Pirogovskaya, 1a, Moscow 119435, Russia; d.matyushkina@gmail.com (D.M.); \\ nikitishena@mail.ru (O.P.) \\ * Correspondence: zhuravleva-inmi@mail.ru; Tel.: +7-499-135-65-96
}

Received: 11 June 2020; Accepted: 17 July 2020; Published: 19 July 2020

\begin{abstract}
Biooxidation of gold-bearing arsenopyrite concentrates, using acidophilic microbial communities, is among the largest commercial biohydrometallurgical processes. However, molecular mechanisms of microbial responses to sulfide raw materials have not been widely studied. The goal of this research was to gain insight into the defense strategies of the acidophilic bacterium Sulfobacillus thermotolerans, which dominates microbial communities functioning in industrial biooxidation processes at $>35^{\circ} \mathrm{C}$, against the toxic effect of the high-arsenic gold-bearing sulfide concentrate. In addition to extreme metal resistance, this acidophile proved to be one of the most As-tolerant microorganisms. Comparative proteomic analysis indicated that 30 out of 33 differentially expressed proteins were upregulated in response to the ore concentrate, while the synthesis level of the functional proteins required for cell survival was not negatively affected. Despite a high level of cellular metal(loid) accumulation, no specific metal(loid)-resistant systems were regulated. Instead, several proteins involved in the metabolic pathways and stress response, including MBL fold metallo-hydrolase, sulfide:quinone oxidoreductase, and GroEL chaperonin, may play crucial roles in resistance to the sulfide ore concentrate and arsenic, in particular. This study provides the first data on the microbial responses to sulfide ore concentrates and advances our understanding of defense mechanisms against toxic compounds in acidophiles.
\end{abstract}

Keywords: acidophiles; Sulfobacillus thermotolerans; sulfide concentrate; arsenic; resistance; differential proteomics; cellular element content

\section{Introduction}

Microbial biomining has been successfully used in industrial operations for decades. Natural and man-made habitats of biomining acidophilic microorganisms include sulfide ore deposits, geothermal sites, metal and coal mines with acid mine drainage, sulfate soils, pit lakes, mine heaps, and waste rock dumps [1]. Due to the ability of acidophilic chemolithotrophic microorganisms (ACMs) to oxidize ferrous iron, elemental sulfur, reduced sulfur compounds, and metal sulfides, numerous biohydrometallurgical approaches, using ACM communities, have been developed [2]. These biotechnologies are applied worldwide to recover valuable metals from the ores and ore concentrates, as well as metallurgical slags and other waste materials. Several biotechnologies (BIOX ${ }^{\circledR}$, BioCOP $^{\circledR}$, BioNIC $^{\circledR}$, etc.) have been commercialized [1]. 
Gram-positive mixotrophic bacteria of the genus Sulfobacillus (Sb.) predominate in ACM communities in natural habitats and industrial processes of bioleaching/biooxidation of sulfide ores and ore concentrates. Due to the unique ability to oxidize all mineral substrates listed above (in the presence of small amounts of organic matter), these bacteria are widely used for the recovery of precious and other nonferrous metals at temperatures $>35^{\circ} \mathrm{C}$ [2-4]. One of the species, Sb. thermotolerans, has been found to dominate different ACM communities during bioleaching of sulfide raw materials containing gold, silver, zinc, and some other nonferrous metals at $35-45^{\circ} \mathrm{C}$ [5-10]. Sb. thermotolerans is continuously identified as the predominant bacterium in the biomining microbial communities during laboratory-scale and industrial processes of bioleaching/biooxidation of refractory gold ores [6,11-13]. This thermotolerant species possesses a versatile metabolism, which provides for its functioning under fluctuating conditions of natural environments and technological processes (changes in $\mathrm{pH}$ and temperature, pulp density, concentrations of heavy metals and metalloids, as well as the availability of energy substrates and oxygen or other electron acceptors to cells) [8,14-16].

In industrial operations, components of sulfide concentrates (heavy metals and metalloids) can be accumulated to high levels in bioleaching tanks. Therefore, the microbial step of ore processing requires communities of acidophiles that are resistant to high pulp densities and increased contents of metal(loid)s in the liquid phase. Biooxidation of gold-bearing arsenopyrite concentrates, using ACM communities, is among the largest commercial processes. Most arsenopyrite biooxidation processes operate at $40{ }^{\circ} \mathrm{C}$ and are dominated by communities of the sulfur- and iron-oxidizing microorganisms [17]. Some chemolithotrophs, including Sulfobacillus and Acidithiobacillus (At.) ferrooxidans strains, are tolerant to high ambient concentrations of heavy metals, which are toxic to the majority of other microorganisms at significantly lower (1-2 orders of magnitude) values; $S b$. thermotolerans proved to be resistant to at least $765 \mathrm{mM} \mathrm{Zn}^{2+}$ and $30 \mathrm{mM} \mathrm{Cu}^{2+}[16]$.

Most studies of the heavy metal resistance mechanisms in acidophiles, including proteomic research, have focused on At. ferrooxidans [18-25] and some other acidophilic bacteria and archaea: At. thiooxidans, At. caldus, At. ferrivorans, Leptospirillum (L.) ferrooxidans and L. ferriphilum, Ferroplasma (F.) acidarmanus, Sulfolobus (Sl.) metallicus and Sl. sulfotaricus, and Acidimicrobium (Am.) ferrooxidans [26-30]. Analysis of the genomes of acidophiles has revealed metal resistance determinants varying in content and quantity. These microorganisms harbor metal resistance systems that are responsible for the import and efflux of heavy metal ions, as well as their extra- and intracellular sequestration and transformation to less toxic compounds $[16,18,19,27,29,31]$. Although complexation of metals in acidic media partially explains the phenomenon of extreme metal resistance in acidophiles [32], the differing levels of metal tolerance in acidophiles under similar growth conditions imply the involvement of other mechanisms for high metal resistance.

During the treatment of arsenic gold-bearing sulfide ores, large quantities of arsenic are released into continuous-flow aeration tanks, in which biooxidation takes place [17]. Research into the arsenic tolerance of biomining microorganisms has indicated that the acquisition of additional arsenic resistance determinants by some At. caldus and L. ferriphilum strains may be associated with their improved growth under arsenic stress [31]. The proteomic response of L. ferriphilum to arsenic seems to involve the arsenic resistance system, phosphate regulation, and glutathione synthesis [33]. According to the differential gene expression, the arsenic efflux system is an important pathway of arsenite detoxification in L. ferriphilum and At. thiooxidans strains [34].

A number of works have been devoted to the mechanisms of oxidation of some pure metal sulfides. The protein expression during At. ferrooxidans growth on the media containing pyrite, bornite, or chalcopyrite has been studied [35-37]. While the response of At. ferrooxidans to bornite exposure involved 13 proteins, mainly related to energy metabolism, detoxification, and protein synthesis, chalcopyrite contact did not lead to a significant alteration in the level of protein expression [36]. In another At. ferrooxidans strain, a small decrease in the rus operon gene expression was observed in the presence of chalcopyrite, while the presence of covellite caused a remarkable decrease in the expression of these genes [38]. Adaptations of L. ferriphilum to growth on chalcopyrite include the possibly 
enhanced production of reducing power, reduced carbon dioxide fixation, enhanced chemotaxis and motility, as well as elevated levels of RNA transcripts and proteins involved in heavy metal resistance, with special emphasis on copper efflux systems [39]. The gene expression analysis has indicated that Acidithiobacillus sp. FJ2 can survive and leach uranium under the stress conditions of different uranium ore pulp densities (up to $50 \%$ ) by modulation in the rus operon gene responses, increasing the expression levels of the $c y c 2, c y c 1, r u s$, and $\operatorname{coxB}$ genes [25]. Different research groups have studied the proteomic changes that are involved in the biofilm formation by two Gram-negative acidophilic bacteria: At. ferrooxidans [37,40,41] and Leptospirillum spp. [42-44]. The formation of biofilms is considered to be one of the central aspects of the bioleaching of sulfide ores and ore concentrates.

Although numerous works have been devoted to the interactions of acidophilic microorganisms with metal(loid)s and some pure metal sulfides, little is known about the molecular mechanisms of microbial responses to sulfide raw materials, including arsenic-containing sulfide concentrates. To our knowledge, no data on the molecular responses of chemolithotrophic acidophiles to sulfide concentrates containing nonferrous (including precious) metals, and, particularly, arsenopyrite concentrates of gold-bearing sulfide ores, have been reported. At the same time, biotechnologies for processing of complex sulfide raw materials are widely applied, and studies of the mechanisms of responses of biotechnological microbial cultures to arsenic-rich sulfide concentrates are of interest and importance for the optimization of bioleaching operations. The goal of this study was to gain insight into the defense strategies of $S b$. thermotolerans against toxic effects of the high-arsenic gold-bearing sulfide concentrate. The research objectives were to investigate its effect on the growth and oxidative activity of $\mathrm{Sb}$. thermotolerans, proteome reorganization, and cellular accumulation of metal(loid)s.

\section{Materials and Methods}

\subsection{Materials}

The flotation concentrate of the gold-bearing pyrite-arsenopyrite sulfide ore was used in the experiments. The mineral composition of the ore concentrate was as follows: $\mathrm{FeS}_{2}(48 \mathrm{wt} \%), \mathrm{FeAsS}$ (35 wt \%), $\mathrm{ZnS}, \mathrm{CuFeS}_{2}, \mathrm{PbS}, \mathrm{Au}(135.2 \mathrm{~g} / \mathrm{t})$, and $\mathrm{Ag}(160 \mathrm{~g} / \mathrm{t})$. The contents of sulfidic sulfur $\left(\mathrm{S}_{\mathrm{S}}\right)$ and sulfidic arsenic ( $\mathrm{As}_{\mathrm{S}}$ ) in the ore concentrate were 28.1 and $16 \mathrm{wt} \%$, respectively. Table 1 shows the chemical composition of the ore concentrate. The particle size distribution of the concentrate sample had a $\mathrm{P}_{80}$ of $44 \mu \mathrm{m}$.

Table 1. Contents of the main elements in the original sulfide concentrate and concentrations of metal(loid)s in the liquid phase after $80 \mathrm{~h}$ of cultivation with Sb. thermotolerans Kr1.

\begin{tabular}{|c|c|c|c|}
\hline \multicolumn{2}{|c|}{ Element } & \multirow{3}{*}{$\begin{array}{c}\begin{array}{c}\text { Content }(w t \%), \\
\text { Original Concentrate }\end{array} \\
38.7 \pm 0.51 \\
34.9 \pm 0.89 \\
\end{array}$} & \multirow{3}{*}{$\begin{array}{c}\text { Element Concentration }(\mathbf{m M}), \\
\text { Liquid Phase (after } 80 \text { h) } \\
39.0 \pm 2.2\end{array}$} \\
\hline & $\mathrm{Fe}_{\text {tot }}{ }^{\mathrm{a}}$ & & \\
\hline $\mathrm{Fe}$ & $\mathrm{Fe}_{\mathrm{S}} \mathrm{b}$ & & \\
\hline \multirow{2}{*}{$S$} & $S_{\text {tot }}$ & $28.25 \pm 0.76$ & \multirow{2}{*}{$27.1 \pm 1.5$} \\
\hline & $\mathrm{S}_{\mathrm{S}}$ & $28.1 \pm 0.95$ & \\
\hline \multirow{2}{*}{ As } & $\mathrm{As}_{\text {tot }}$ & $19.1 \pm 0.75$ & \multirow{2}{*}{$35.3 \pm 3.7\left(4.4 \mathrm{As}^{5+}\right.$ and $\left.30.9 \mathrm{As}^{3+}\right)$} \\
\hline & $\mathrm{Ass}_{\mathrm{S}}$ & $16 \pm 0.15$ & \\
\hline \multicolumn{2}{|c|}{$\mathrm{Sb}$} & $0.15 \pm 0.03$ & $\mathrm{nd}^{\mathrm{c}}(<0.550)$ \\
\hline \multicolumn{2}{|c|}{$\mathrm{Zn}$} & $0.72 \pm 0.02$ & $1.5 \pm 0.1$ \\
\hline \multicolumn{2}{|c|}{$\mathrm{Cu}$} & $0.04 \pm 0.01$ & nd $(<0.077)$ \\
\hline \multicolumn{2}{|c|}{$\mathrm{Pb}$} & $1.21 \pm 0.06$ & nd $(<0.190)$ \\
\hline \multicolumn{2}{|c|}{$\mathrm{Au}$} & $135.2 \pm 1.61 \mathrm{~g} / \mathrm{t}$ & $-d$ \\
\hline \multicolumn{2}{|c|}{$\mathrm{Ag}$} & $160 \pm 2.35 \mathrm{~g} / \mathrm{t}$ & - \\
\hline
\end{tabular}

a Tot: Total; ${ }^{\mathrm{b}}$ The index $s$ indicates the content of the element in sulfidic minerals; ${ }^{\mathrm{c}}$ nd: Not detected (the value is below the test-sensitivity level, which is shown in parentheses); ${ }^{\mathrm{d}} \mathrm{Au}$ and Ag are in sulfides. Mean values $\pm \mathrm{SD}(p \leq$ $0.05)$ are shown. 


\subsection{Research Object and Cultivation Conditions}

Sb. thermotolerans strain $\mathrm{Kr}^{\mathrm{T}}\left(\mathrm{VKM} \mathrm{B}-2339^{\mathrm{T}}=\mathrm{DSM} 17362^{\mathrm{T}}\right)$ that was used in this study was obtained from the Collection of Microorganisms of Winogradsky Institute of Microbiology, Russian Academy of Sciences (Moscow, Russia). The strain was cultured in $250 \mathrm{~mL}$ Erlenmeyer flasks (100 mL of the liquid medium) on a Unimax-1010 rotor shaker (Heidolph Instruments, Schwabach, Germany; $220 \mathrm{rpm}$ ) in an Inkubator-1000 thermostat (Heidolph Instruments, Schwabach, Germany). Experiments were carried out using the modified $9 \mathrm{~K}$ medium [16] containing ferrous sulfate $\left(48 \mathrm{mM} \mathrm{Fe}^{2+}\right)$ as an energy source and yeast extract $(0.02 \%, w / v)$. The $9 \mathrm{~K}$ medium supplemented with 10,20 , or $30 \mathrm{~g} / \mathrm{L}$ ore concentrate instead of ferrous iron was used to determine the characteristics of $S b$. thermotolerans $\mathrm{Kr} 1$ growth and substrate oxidation in the presence of different amounts of the sulfide concentrate. To obtain the biomass for a subsequent proteomics analysis and determination of the cellular element content, the strain $\mathrm{Kr} 1$ was grown in $2500 \mathrm{~mL}$ Erlenmeyer flasks containing $1500 \mathrm{~mL}$ of the modified $9 \mathrm{~K}$ medium and ferrous iron $\left(48 \mathrm{mM} \mathrm{Fe}^{2+}\right)$ or $2 \%(w / v)$ ore concentrate with mixing by air agitation (sterile air was supplied at a flow rate of $2 \mathrm{~L} \mathrm{~min}^{-1}$ ) in a Redline RI 53 incubator (Binder, Tuttlingen, Germany). In all experiments, $S b$. thermotolerans $\mathrm{Kr} 1$ was cultured at $39 \pm 1{ }^{\circ} \mathrm{C}$. The initial ambient $\mathrm{pH}$ value was adjusted to 1.7 with $10 \mathrm{~N} \mathrm{H}_{2} \mathrm{SO}_{4}$. The amount of inoculum was $10 \%(v / v)$.

\subsection{Cell Treatment and Pellet Lysis}

For subsequent proteomics analysis and determination of cellular elements, late-exponential cells of $\mathrm{Sb}$. thermotolerans $\mathrm{Kr} 1$ were collected by centrifugation $\left(10,000 \times g, 15 \mathrm{~min}, 4^{\circ} \mathrm{C}\right)$ and treated as further described below. To assess the total cellular and intracellular element accumulation, two types of Sb. thermotolerans samples were used. The first one (for the determination of the total cellular concentrations of elements) contained intact cells that were washed in the acidified salt base of the iron-free $9 \mathrm{~K}$ medium. Cells were further pelleted by centrifugation $\left(10,000 \times g, 15 \mathrm{~min}, 4^{\circ} \mathrm{C}\right)$ and dried overnight at $80^{\circ} \mathrm{C}$ to calculate the dry weight of the cell pellet. The second variant (determination of the intracellular element concentration) contained cell-free lysates that were obtained after sonication of $S b$. thermotolerans cells using a UZDN-2T ultrasonic disintegrator (Akadempribor, Sumy, Ukraine) (1.5 min with 2-min intervals for cooling, four times; $22 \mathrm{~Hz}, 40 \mathrm{~mA})$ and subsequent centrifugation $(40,000 \times g$, $30 \mathrm{~min}, 4^{\circ} \mathrm{C}$ ) to pellet cell debris. Prior to the ultrasound disintegration, metals were desorbed from cell walls. To achieve this, cells were rinsed with acidified distilled water (three times), centrifuged, suspended in a $50 \mathrm{mM}$ Tris- $\mathrm{HCl}$ buffer $(\mathrm{pH}$ 6.8) containing $1 \mathrm{mM}$ EDTA (ethylenedinitrilotetraacetic acid) (10 $\mathrm{min})$, and washed from EDTA with the latter buffer. Lysates were air-dried to concentrate cellular contents for subsequent determination of elements by analytical techniques (Section 2.6). For proteomics studies, cell pellets were washed twice with the salt base of the $9 \mathrm{~K}$ medium ( $\mathrm{pH} 1.8$ ) containing no energy substrates, washed with a $50 \mathrm{mM}$ Tris- $\mathrm{HCl}$ buffer ( $\mathrm{pH}$ 6.8), and suspended in the latter. The suspension in the buffer was supplemented with $1 \mathrm{mM}$ EDTA and $1 \mathrm{mM}$ PMSF (phenylmethylsulfonyl fluoride; Sigma-Aldrich, Steinheim, Germany) and stored at $-70{ }^{\circ} \mathrm{C}$ prior to the proteomic analysis.

\subsection{Proteomic Analysis}

\subsubsection{Two-Dimensional Difference Gel Electrophoresis (2D DIGE)}

Prior to the 2D DIGE, $S b$. thermotolerans cell pellets were treated with a $5-\mu \mathrm{L}$ mixture of $30 \%$ CHAPS (3-[(3-Cholamidopropyl)dimethylammonio]-1-propanesulfonate) and 10\% NP40 detergents (Sigma-Aldrich, Steinheim, Germany) and a 1- $\mu \mathrm{L}$ mixture of nucleases (Nuclease Mix, GE Healthcare, Amersham, UK). The cell pellets were incubated for $30 \mathrm{~min}$ at $4{ }^{\circ} \mathrm{C}$ and dissolved in the buffer for isoelectric focusing ( $40 \mathrm{mM}$ Tris- $\mathrm{HCl}, \mathrm{PH} 9.5$ ), containing the following: $8 \mathrm{M}$ urea, $2 \mathrm{M}$ thiourea, $4 \%$ CHAPS, and $2 \%$ NP40. The samples were centrifuged at $14,000 \times g$ for $15 \mathrm{~min}$. Protein concentration in the samples was measured by the Bradford method using the Quick Start Bradford dye (Bio-Rad, Hercules, CA, USA). The sample proteins were labeled with Cy3 (green) or Cy5 (red) CyDye DIGE 
Fluor minimal dyes (Amersham Biosciences, Vienna, Austria) according to the manufacturer's recommendations ( $400 \mathrm{pmol}$ per $50 \mu \mathrm{g}$ protein). The binding reaction of cyanines with protein was stopped by adding a $10 \mathrm{mM}$ lysine solution. DTT (dithiothreitol; to the final concentration of $100 \mathrm{mM}$ ) and Ampholine 3-10 (to 1\%) (Bio-Rad, Hercules, CA, USA) were subsequently added. Prior to mixing a pair of the samples compared, we performed an electrophoretic separation of each of them by $12 \%$ PAGE under denaturing conditions. After electrophoresis, the gel was scanned on the TyphoonTrio scanner (Amersham Biosciences, Vienna, Austria) at a laser wavelength of $532 \mathrm{~nm}$ (green fluorescence) and $633 \mathrm{~nm}$ (red fluorescence). The value of the total fluorescence intensity was detected for each sample. Given these values, the two samples labeled with a different cyanine were mixed in a certain ratio, based on the overall alignment of the fluorescence intensity values for each of them. Isoelectrofocusing was performed in 18-cm glass tubes in $4 \%$ polyacrylamide gel of the following composition: $8 \mathrm{M}$ urea, $2 \%$ ampholines ( $\mathrm{pH} 3-10), 4 \%$ ampholines ( $\mathrm{pH} 5-8), 6 \%$ solution containing 30\% CHAPS and 10\% NP40, 0.1\% TEMED ( $\mathrm{N}, \mathrm{N}_{,} \mathrm{N}^{\prime}, \mathrm{N}^{\prime}$-tetramethylethane-1,2-diamine), and $0.02 \%$ ammonium persulfate. The total protein content was 200-250 $\mu \mathrm{g}$ per tube. Isoelectrofocusing was performed in the following mode: 100, 200, 300, 400, 500, and $600 \mathrm{~V}$ (45 min); $700 \mathrm{~V}$ (10 h); and $900 \mathrm{~V} \mathrm{(1} \mathrm{h).} \mathrm{On} \mathrm{completion} \mathrm{of}$ isoelectrofocusing, the tubes were equilibrated (for $30 \mathrm{~min}$ ) in the buffer containing the following: 6 M urea, 30\% glycerol, $62.5 \mathrm{mM}$ Tris- $\mathrm{HCl}$ (pH 6.8), 2\% SDS, $20 \mathrm{mM} \mathrm{DTT}$, and bromophenol blue. The tubes were subsequently transferred to the surface of the gradient polyacrylamide gel (9-16\%) and fixed with $0.9 \%$ agarose using bromophenol blue. Electrophoresis was performed in a Tris-glycine buffer under the following conditions: $20 \mathrm{~mA}$ on glass $(20 \mathrm{~min}), 40 \mathrm{~mA}$ on glass $(2 \mathrm{~h})$, and $35 \mathrm{~mA}$ on glass $(2.5 \mathrm{~h})$ with chamber cooling to $10^{\circ} \mathrm{C}$. The results were analyzed by the PDQuest 8.0 software (Bio-Rad, Hercules, CA, USA). For spot excision, the gels were silver stained as described [45].

\subsubsection{Trypsin Digestion and MALDI Mass Spectrometry}

The protein spots (after 2D DIGE) were subjected to trypsin in-gel hydrolysis as described [46]. Gel pieces of $2 \mathrm{~mm}^{3}$ were excised and washed with $10 \mu \mathrm{L}$ of a $15 \mathrm{mM}$ sodium thiosulfate and $50 \mathrm{mM}$ potassium hexacyanoferrate (III) mixture for $10 \mathrm{~min}$ at room temperature, washed twice with deionized water, dehydrated with $100 \mu \mathrm{L}$ of acetonitrile, and air-dried. The gel pieces were subsequently treated with $3 \mu \mathrm{L}$ of a $15 \mathrm{mg} / \mathrm{mL}$ trypsin solution (Promega, Madison, WI, USA) in $50 \mathrm{mM}$ ammonium bicarbonate for $16 \mathrm{~h}$ at $37^{\circ} \mathrm{C}$. Peptides were extracted with a $0.5 \%$ trifluoroacetic acid water solution $(6 \mu \mathrm{L})$ for $30 \mathrm{~min}$.

Aliquots $(2 \mu \mathrm{L})$ of the sample were mixed on a ground steel target with a $0.5 \mu \mathrm{L}$ of 2,5-dihydroxybenzoic acid (Sigma-Aldrich, Steinheim, Germany) solution (30 mg/mL in 30\% acetonitrile/ $0.5 \%$ trifluoroacetic acid), and the droplet was left to dry at room temperature. Mass spectra were recorded on an Ultraflex II MALDI-ToF-ToF mass spectrometer (Bruker Daltonik, Bremen, Germany) equipped with $\mathrm{Nd}$ laser. The $[\mathrm{M}+\mathrm{H}]^{+}$molecular ions were measured in a reflector mode; the accuracy of mass peak measurement was $70 \mathrm{ppm}$.

\subsubsection{Protein Identification}

Proteins were identified by the peptide fingerprint search with Mascot software (Matrix Science Inc., Boston, MA, USA) through the $\mathrm{Sb}$. thermotolerans $\mathrm{Kr} 1$ protein database (accession number CP019454; https://www.ncbi.nlm.nih.gov/nuccore/CP019454.1?report=genbank). Protein scores greater than 45 were considered significant $(p<0.05)$. The quantitative assessment was performed with the PDQuest 8.0 software (Bio-Rad, Hercules, CA, USA). Differentially expressed proteins with a fold change of $\geq 2.0$ were discussed.

\subsection{Protein Characterization and Pathway Mapping}

Functional characterization of the proteins of interest, encoded by the genome of $\mathrm{Sb}$. thermotolerans $\mathrm{Kr1}$, was carried out using the KOALA (KEGG Orthology and Links Annotation) system [47]. Pathway mapping was carried out using tools of the KEGG software package. 


\subsection{Analytical Techniques}

The $\mathrm{pH}$ value and concentrations of $\mathrm{Fe}^{3+}$ and $\mathrm{Fe}^{2+}$ were measured as previously described [16]. Arsenic in the liquid phase was determined by iodometric titration involving the binding of iron ions with $\mathrm{TiCl}_{3}$ as reported [48]. The concentrations of zinc and copper in the growth media were measured using a Perkin Elmer 3100 flame atomization atomic absorption spectrometer (PerkinElmer, Waltham, MA, USA). The chemical composition of the concentrate (iron, arsenic, and other elements) was determined using an inductively coupled plasma atomic emission spectrometer (Optima-4300 DV, PerkinElmer, Waltham, MA, USA) according to the manufacturer's recommendations. The sulfur content was measured by the gravimetric analysis [10]. The sulfate concentration was measured turbidimetrically as described [8]. The mineralogical composition of the sulfide concentrate was determined by X-ray diffraction (PANalytical X'Pert PRO MPD, Almelo, The Netherlands). The sulfidic mineral contents were adjusted according to the element contents.

In cell samples, zinc, copper, lead, gold, silver, antimony, arsenic, and iron were measured using inductively coupled plasma mass spectrometry (Elan-6100, PerkinElmer, Waltham, MA, USA) and inductively coupled plasma atomic emission spectroscopy (Optima-4300 DV, PerkinElmer, Waltham, MA, USA) according to the manufacturer's recommendations.

The quantitative assessment of microorganisms was carried out by direct counts in the Goryaev chamber and by the method of serial terminal ten-fold dilutions using a Mikmed-2 microscope (LOMO, St. Petersburg, Russia) equipped with a phase contrast device. Microscopy was also used to determine morphological alterations within the cell population of $\mathrm{Sb}$. thermotolerans.

\subsection{Statistical Methods}

Chemical and mineral analyses were carried out in duplicate with three replicates (ore concentrate) and in two experiments with three samples and three series of measurements for each sample (elements in cells and the liquid phase). Two series of experiments on the bacterial growth included three parallels (flasks) and three replicates for each measured parameter. Statistical processing was performed using Microsoft Excel 2010. The standard deviation (SD) of the arithmetic mean was calculated, and the significance of the results was assessed using the Student's $t$-test at the significance level $p \leq 0.05$. Two series of proteomic experiments under different growth conditions and three protein extractions (biological replicates) with three or four 2D gels for each extraction were carried out. Data were statistically processed using the PDQuest 8.0 software (Bio-Rad, Hercules, CA, USA). The means of three biological replicates in two experiments $( \pm \mathrm{SD})$ were discussed.

\section{Results and Discussion}

\subsection{Toxic Effect of Sulfide Concentrate on Bacterial Growth and Oxidative Activity}

A comparison of the growth and oxidative characteristics of the Sb. thermotolerans $\mathrm{Kr} 1$ that was not preliminarily adapted to the presence of the ore concentrate $(10,20$, or $30 \mathrm{~g} / \mathrm{L}$ ) indicated the following. An increase from 10 to $20 \mathrm{~g} / \mathrm{L}$ resulted in insignificant changes in the maximum cell yields: 3.5 and 3.0 $\times 10^{8}$ cells $/ \mathrm{mL}$, respectively (Figure S1a,b). However, the maximum specific growth rate decreased $\sim 3$ times $\left(\mu_{\max }, 0.33\right.$ and $0.12 \mathrm{~h}^{-1}$ at 10 and $20 \mathrm{~g} / \mathrm{L}$, respectively), and the maximum iron oxidation rate ( $V_{\max }, 4.7$ and $1.8 \mathrm{mM} / \mathrm{h}$, respectively) decreased more than 2.5 times. A 10-h lag phase preceded the active growth and oxidation. According to microscopic observations, $\sim 1-1.5 \%$ of forespores (an intermediate stage between a vegetative cell and a dormant spore) were present in the cell population. During $117 \mathrm{~h}$ of cultivation, the $\mathrm{pH}$ values varied within 1.7-1.9. At all points of the curve, zero $\mathrm{Fe}^{2+}$ concentration was detected, indicating the rapid oxidation of the leached ferrous iron to ferric iron. Overall, changes in the growth parameters, which were observed in the presence of $20 \mathrm{~g} / \mathrm{L}$ of the sulfide concentrate, indicated partial inhibition of microbial activity (toxic effect on microbial cells) by the components of the ore concentrate. We observed a significant suppression of the growth of the 
nonadapted $\mathrm{Sb}$. thermotolerans $\mathrm{Kr} 1$ culture in response to $30 \mathrm{~g} / \mathrm{L}$ of the ore concentrate in the medium $\left(\mu_{\max }, 0.02 \mathrm{~h}^{-1} ; V_{\max }, 0.5 \mathrm{mM} / \mathrm{h}\right)$ (Figure S1c).

Based on these results, we selected two variants for subsequent studies of the mechanisms of resistance to the arsenopyrite concentrate. Sb. thermotolerans $\mathrm{Kr} 1$ was grown in the presence of $20 \mathrm{~g} / \mathrm{L}$ sulfide concentrate (the final growth and oxidation parameters were $2.2 \times 10^{8}$ cells $/ \mathrm{mL}$ and $39 \mathrm{mM}$ $\mathrm{Fe}^{3+}$, respectively; Figure S1b) and under the optimal growth conditions (control) when ferrous iron was used as an energy substrate (final parameters were $3.0-3.1 \times 10^{8}$ cells $/ \mathrm{mL}$ and $43 \mathrm{mM} \mathrm{Fe}^{3+}$; Figure S1d). As mentioned above, the ore concentrate $(20 \mathrm{~g} / \mathrm{L})$ had a certain toxic effect on the growth of $S b$. thermotolerans $\mathrm{Kr1}$. The latter, however, was able to adapt to its presence during cultivation. Due to the sufficient bacterial growth under these stressful conditions, it was, therefore, possible to study the proteomic response of the strain and to analyze the cellular contents of metal(loid)s.

\subsection{Metal Accumulation by Cells}

The sulfide concentrate used in this study was characterized by a high content of As (19.1 wt \%), as well as the presence of $\mathrm{Zn}$, which also contributed to the toxic effect on the bacterial cells. During biooxidation of the sulfide ore concentrate, ferrous iron, arsenic, and zinc were gradually released from the solids into the medium (Table 1). The cellular contents of several metal(loid)s accumulated by the late-exponential $\mathrm{Sb}$. thermotolerans cells significantly increased compared to those under the optimal growth conditions (Table 2).

Table 2. Total cellular accumulation and intracellular concentrations of metal(loid)s at the lateexponential phase of $\mathrm{Sb}$. thermotolerans growth.

\begin{tabular}{|c|c|c|c|c|}
\hline \multirow{3}{*}{ Element } & \multicolumn{4}{|c|}{ Growth Conditions } \\
\hline & \multicolumn{2}{|c|}{ Optimal } & \multicolumn{2}{|c|}{ Ore Concentrate, $20 \mathrm{~g} / \mathrm{L}$} \\
\hline & $C_{\text {tot }}, \mu g / g^{a}$ & $C_{\text {intra}}, \mu g / g^{b}$ & $\mathrm{C}_{\text {tot}}, \mu \mathrm{g} / \mathrm{g}^{\mathrm{a}}$ & $\mathrm{C}_{\text {intra}}, \mu \mathrm{g} / \mathrm{g}^{\mathrm{b}}$ \\
\hline $\mathrm{Fe}$ & $60210 \pm 350$ & $830 \pm 4.9$ & $6515 \pm 59$ & $588 \pm 6$ \\
\hline $\mathrm{Zn}$ & $53.5 \pm 1.5$ & $31.7 \pm 2.5$ & $1338 \pm 74$ & $463 \pm 5.9$ \\
\hline $\mathrm{Cu}$ & $29 \pm 0.54$ & $16 \pm 0.7$ & $165.5 \pm 18$ & $125 \pm 7$ \\
\hline $\mathrm{Pb}$ & $2.85 \pm 0.36$ & $<0.00098^{c}$ & $370 \pm 16.7$ & $74 \pm 2.7$ \\
\hline $\mathrm{Ag}$ & $1.35 \pm 0.25$ & $<0.066^{\mathrm{c}}$ & $135.5 \pm 6.4$ & $10 \pm 1.4$ \\
\hline $\mathrm{Au}$ & $0.027 \pm 0.003$ & $<0.0017^{\mathrm{c}}$ & $11.8 \pm 0.6$ & $9.9 \pm 0.5$ \\
\hline As & $1.75 \pm 0.07$ & $0.94 \pm 0.17$ & $941 \pm 46$ & $233.5 \pm 6$ \\
\hline $\mathrm{Sb}$ & $1.7 \pm 0.1$ & $0.33 \pm 0.1$ & $53.5 \pm 5.7$ & $26.5 \pm 2.3$ \\
\hline
\end{tabular}

${ }^{a} C_{\text {tot }}$ and ${ }^{b} C_{\text {intra }}$ : Total cellular and intracellular element concentration, respectively ( $\mu g$ per g dried biomass); ${ }^{\mathrm{c}}$ the value is below the test-sensitivity level. Mean values $\pm \operatorname{SD}(p \leq 0.05)$ are shown.

After $80 \mathrm{~h}$ of growth, $1.5 \mathrm{mM} \mathrm{Zn}^{2+}$ was released (Table 1). Except for iron, the total zinc sorption by the cells and intracellular accumulation of zinc were at the highest levels among all elements; they increased 25 and 15 times, respectively, compared to the control values (Table 2). At the same time, while iron absorption was similar in both variants $(0.6-0.8 \mathrm{mg} / \mathrm{g}$ dry weight), total iron accumulation was one order of magnitude lower than in the variant grown under the optimal conditions (6.5 and $60.2 \mathrm{mg} / \mathrm{g}$ dry weight, respectively). This may result from a slow rate of ferrous iron leaching from the sulfide concentrate, competition of metal ions for the binding sites on the cell surface, and specific characteristics of the cell envelope of $S b$. thermotolerans $\mathrm{Kr} 1$ [8]. In the presence of $\mathrm{Cr}^{6+}$, Fe sorption by the biomass of the yeast Saccharomyces (Sc.) cerevisiae, fungus Aspergillus (As.) niger, and bacterium Streptococcus (St.) equisimilis was also partially inhibited [49]. A similar pattern was observed for iron accumulation by the $S c$. cerevisiae stationary-phase cells in the presence of $\mathrm{ZnCl}_{2}$ : While the cellular accumulation of $\mathrm{Zn}$ increased $\sim 25$ times, Fe accumulation decreased three times (from 5 to 13 and from 0.25 to $0.08 \mathrm{mg} / \mathrm{g}$ dry weight, respectively). The amount of intracellular iron decreased in a manner that was dependent on the concentration of zinc in the medium [50]. 
Copper accumulation was $\sim 6-8$ times higher than in the culture grown under the optimal conditions. The total and intracellular Sb content increased $\sim 30$ and 80 times, respectively. The total accumulation of $\mathrm{Ag}, \mathrm{Au}$, and $\mathrm{Pb}$ in the concentrate-grown cells increased at least two orders of magnitude, and the intracellular accumulation of these elements was recorded (Table 2).

Among the most interesting results of this study was the high-level arsenic resistance of $S b$. thermotolerans. In acidic conditions, arsenic is most commonly found as either arsenate $\left(\mathrm{As}^{5+} / \mathrm{AsO}_{4}{ }^{3-}\right)$ or arsenite $\left(\mathrm{As}^{3+} / \mathrm{As}(\mathrm{OH})_{3}\right)$. Arsenate enters the cell via the phosphate uptake system and is toxic by acting as a phosphate analog, while the more toxic arsenite enters cells via aquaglyceroporins and some sugar transporters and is toxic by binding sulfhydryl groups [31]. The total As concentration in the $S b$. thermotolerans $\mathrm{Kr} 1$ growth medium reached a high level of $35.3 \mathrm{mM}\left(4.4 \mathrm{mM} \mathrm{As}{ }^{5+}\right.$ and $30.9 \mathrm{mM} \mathrm{As}^{3+}$ ) after $80 \mathrm{~h}$ of cultivation. Most arsenic was in the highly toxic arsenite $\left(\mathrm{As}^{3+}\right)$ form. These conditions may be compared to the initial stages of processing of arsenopyrite concentrates when a microbial community gradually adapts to increasing concentrations of dissolved metal(loid)s in the liquid phase. The demonstrated growth of Sulfobacillus strains in bioreactors with moderate to high metals concentrations has indicated their strong ability to adapt to the presence of soluble metals in their environment [51]. In laboratory-scale and industrial operations, arsenic concentrations may vary within 8-120 mM at pulp densities of 4-20 wt\%, while iron concentration can reach 250 $\mathrm{mM}[8,12,48,52]$. In fact, a bioleaching microbial community, which contained $\mathrm{Sb}$. thermotolerans and was gradually adapted to this ore concentrate at a high pulp density $(20 \%, w / v)$, tolerated up to 131 $\mathrm{As}^{3+}$ during the long-term bioleaching process (our unpublished data). Another microbial community dominated by $S b$. thermotolerans tolerated at least $81 \mathrm{mM}$ arsenic in the course of bioleaching of a $200 \mathrm{~g} / \mathrm{L}$ gold-bearing pyrite-arsenopyrite ore concentrate that contained $3.63 \% \mathrm{As}_{\mathrm{S}}$ in its original composition [12]. A community consisting of Sb. thermosulfidooxidans and At. ferrooxidans strains tolerated up to 57-115 mM As while oxidizing the ore concentrate of the composition that was similar to the one of the concentrate used by us (40\% $\mathrm{FeS}_{2}$ and 35\% FeAsS (16\% Ass); $\left.134.6 \mathrm{~g} / \mathrm{t} \mathrm{Au;} 200 \mathrm{~g} / \mathrm{t} \mathrm{Ag}\right)$ at 30 and $42{ }^{\circ} \mathrm{C}$ in the $\mathrm{pH}$ range of 1.2-2.0 [48]. Sulfobacillus spp. strains were shown to tolerate up to 25-100 $\mathrm{mM} \mathrm{As}^{5+}$ when pure cultures [51] and microbial communities [53] were used. Other members of acidophilic microbial communities are also known to be highly arsenic-resistant. Thus, L. ferriphilum strains conferred resistance to $40-60 \mathrm{mM} \mathrm{As}^{5+}$ and $\mathrm{As}^{3+}$, while L. ferrooxidans was resistant to $30 \mathrm{mM}$ $\mathrm{As}^{3+}$ and $20 \mathrm{mM} \mathrm{As}{ }^{5+}$ [17]. At. ferrooxidans and At. caldus strains tolerated 20-84 and $30 \mathrm{mM} \mathrm{As}^{3+}$, respectively $[52,54,55]$.

Our study indicated that $S b$. thermotolerans cells accumulated high amounts of As $(0.9 \mathrm{mg} / \mathrm{g}$ dry weight) compared to most other microorganisms. Cellular and intracellular accumulation of As (after $80 \mathrm{~h}$ of cultivation) proved to be 540 and 250 times higher, respectively, than under the optimal conditions of growth. Earlier, we have identified the genes that are involved in the mechanisms of resistance to arsenic $\left(\mathrm{As}^{3+}\right)$ in $\mathrm{Sb}$. thermotolerans $\mathrm{Kr1}$. Although the repressor gene of the arsenic resistance operon $(\operatorname{ars} R)$ is present in the $S b$. thermotolerans $\mathrm{Kr} 1$ genome, no arsenate reductase (arsC) has been identified. At the same time, the ArsA/ArsB ATPase pump, which is predicted to export arsenite and antimonite, is encoded by the $S b$. thermotolerans genome [16].

According to the previous studies, cells of the most arsenic-resistant bacterial strains, which can potentially be used in bioremediation, accumulate up to $\sim 0.025 \mathrm{mg}$ As per $\mathrm{g}$ of cell pellet [56]. The capacity of algal cells of Synechocysis sp. for metal accumulation is similar to Sb. thermotolerans cells: 0.9-1 mg/g dry weight, although the minimum inhibitory concentration value of As for Synechocystis sp. is only $0.5 \mathrm{mM}$ As in the growth medium [57]. Nevertheless, it should be noted that the resistance of these organisms can be compared only indirectly, due to the differences in their cellular organization and conditions of growth. The most amazing examples of arsenic-resistant organisms are Theonella swinhoei (a common Indo-Pacific sponge) and Entotheonella sp. fractions from the sponge. The former has been singled as a hyperaccumulator of arsenic, with the highest As concentration $(8.6 \mathrm{mg} / \mathrm{g}) \mathrm{recorded}$ in any organism from an uncontaminated environment [58], while Entotheonella sp. can tolerate the 
absolute As maximum of $12 \mathrm{mg} / \mathrm{g}$ [59]. Our results revealed a high level of arsenic accumulation by $S b$. thermotolerans, which, however, retained its ability for active growth and substrate oxidation.

In general, a comparison of cellular metal contents in microorganisms, especially metal-resistant chemolithotrophs, is problematic due to scarce information about metal accumulation by growing microbial cells. The biomass of Sc. cerevisiae, As. niger, and St. equisimilis sorbs up to $16-22 \mathrm{mg} \mathrm{Fe} / \mathrm{g}$ dry weight, depending on the cultivation conditions [49], which is approximately 3-5 times lower than the level of $\mathrm{Fe}$ accumulation by $\mathrm{Sb}$. thermotolerans growing cells. The $\mathrm{Zn}$ and $\mathrm{Pb}$ biosorption by Delftia tsuruhatensis (a bacterial strain resistant to metals and isolated from mine tailings) reaches 13 and $45 \mathrm{mg} / \mathrm{g}$ dry weight, respectively [60]. The cell biomass of the most studied Gram-negative acidophilic chemolithotrophic bacteria of the genus Acidithiobacillus sorbs high levels of heavy metals.

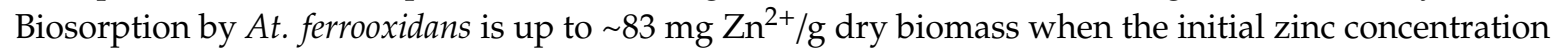
in the culture medium is increased from 25 to $150 \mathrm{mg} / \mathrm{L}$ [61]. The At. thiooxidans biomass absorbs $\mathrm{Zn}$ (95-172 mg/g dry biomass depending on the temperature of cultivation) more efficiently than $\mathrm{Cu}$ (32-40 mg/g) [62], while At. caldus biomass possesses even a higher sorption capacity: Up to $110 \mathrm{mg} / \mathrm{g}$ of $\mathrm{Zn}, 304 \mathrm{mg} / \mathrm{g}$ of $\mathrm{Cu}$, and $310 \mathrm{mg} / \mathrm{g}$ of $\mathrm{Pb}$ [63]. The goal of our experiments with metabolically active growing cells was different from the efficient sorption by cell biomass. Therefore, these values cannot be directly compared. To our knowledge, no data on metal accumulation by acidophiles under similar conditions have been reported, which makes it difficult to assess the efficiency of metal accumulation by $\mathrm{Sb}$. thermotolerans cells. The substantial difference in the metal accumulation by the strain $\mathrm{Kr} 1$ that was grown under optimal and stress conditions (high-arsenic sulfide concentrate) can be noted. Overall, $\mathrm{Sb}$. thermotolerans cells proved to accumulate high concentrations of heavy metals. Despite the high cellular level of metal(loid)s, the strain retained growth and possessed high iron-oxidizing activity. Moreover, according to the concentrations of $\mathrm{As}^{3+}$ released into the culture medium during cultivation and high level of cellular accumulation of arsenic, this bacterium proved to be among the most As-resistant microorganisms.

\subsection{Proteome Reorganization in Response to the Pyrite-Arsenopyrite Concentrate}

The data on the bioinformatics analysis of the Sb. thermotolerans Kr1 genome [16] and a high level of metal accumulation (this study) suggest efficient mechanisms of defense against high concentrations of heavy metals and metalloids. A comparative analysis of the protein profiles of the control variant and the cells grown in the presence of the sulfide concentrate (Figure $1 \mathrm{a}, \mathrm{b}$ ) was the principal study to elucidate the possible strategies of metal(loid) resistance in this bacterium.

(a)

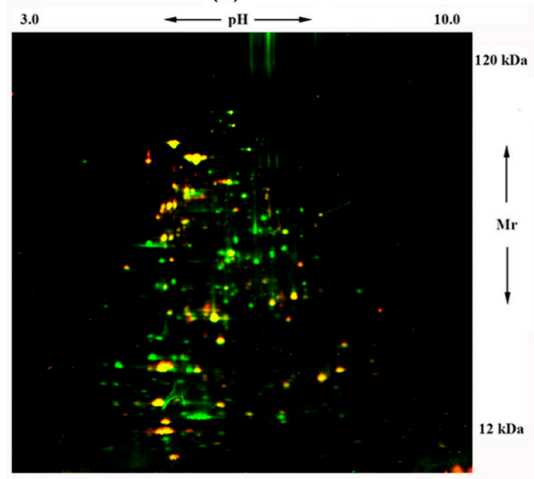

(b)

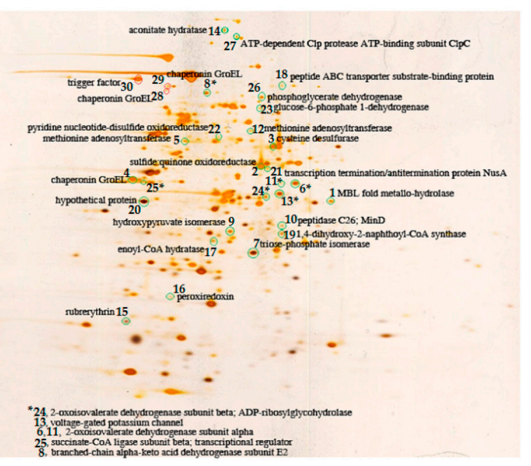

Figure 1. Two-dimensional (2D) DIGE analysis of Sb. thermotolerans cells grown in the presence of the arsenopyrite concentrate (Cy3 dye, green) and in the control medium (Cy5 dye, red) (a) and a corresponding silver-stained gel (b). Arrows (a) indicate $\mathrm{pH}(3-10)$ and $\mathrm{Mr}(12-120 \mathrm{kDa})$ ranges. Circled spots (b) correspond to proteins $\geq 2$-fold up- (green circles) or downregulated (red circles) in response to the concentrate (spot numbers refer to Table 3) and identified by MALDI (Matrix-Assisted Laser Desorption/Ionization) mass spectrometry. 
Table 3. Proteome reorganization in the Sb. thermotolerans cells grown under optimal conditions (Cy5, red) and in the presence of the gold-bearing arsenopyrite concentrate (Cy3, green). Protein spot numbers and ratios in green or red indicate up- or downregulation, respectively, in response to the sulfide concentrate.

\begin{tabular}{|c|c|c|c|c|}
\hline Protein Spot No. ${ }^{\text {a }}$ & Putative Homolog & Protein ID, Size (a. a.) & Function(s) & Су3/Cy5 Ratio \\
\hline 1 & MBL fold metallo-hydrolase & BXT84_14770, 312 & $\begin{array}{l}\text { Hydrolytic enzymes that include class B } \\
\text { ß-lactamases, hydroxyacylglutathione hydrolases, } \\
\text { persulfide dioxygenases, flavodiiron proteins, } \\
\text { insecticide hydrolases. }\end{array}$ & $6.3 \pm 0.82$ \\
\hline 2 & $\begin{array}{l}\text { Sulfide:quinone oxidoreductase } \\
\text { [EC 1.8.5.4] }\end{array}$ & BXT84_01945, 379 & $\begin{array}{l}\text { Reaction of transformation of } \mathrm{H}_{2} \mathrm{~S} \text { to polysulfide, } \\
\text { in which two electrons are transferred to the } \\
\text { electron chain by quinone. Energy production and } \\
\text { conversion. Sulfur metabolism. }\end{array}$ & $5.8 \pm 0.75$ \\
\hline 3 & Cysteine desulfurase & BXT84_05690, 406 & $\begin{array}{l}\text { Removal of elemental sulfur and selenium atoms } \\
\text { from L-cysteine, L-cystine, L-selenocysteine, and } \\
\text { L-selenocystine to produce L-alanine. Amino acid } \\
\text { transport, metabolism, and degradation. Biosynthesis of } \\
\text { cofactors, prosthetic groups, and carriers. }\end{array}$ & $5.4 \pm 0.70$ \\
\hline 4 & Chaperonin GroEL & BXT84_08625, 548 & $\begin{array}{l}\text { Productive folding of proteins. Chaperones, } \\
\text { chaperonins, stress proteins, etc. }\end{array}$ & $5.3 \pm 0.69$ \\
\hline 5 & $\begin{array}{l}\text { S-adenosylmethionine } \\
\text { synthetase [EC 2.5.1.6] }\end{array}$ & BXT84_12950, 399 & $\begin{array}{c}\text { DNA methylation. Control of gene expression. } \\
\text { Coenzyme transport and metabolism. Gene } \\
\text { transcription. Cell proliferation. }\end{array}$ & $5.0 \pm 0.65$ \\
\hline 6 & $\begin{array}{c}\text { 2-Oxoisovalerate } \\
\text { dehydrogenase subunit alpha }\end{array}$ & BXT84_00985, 331 & $\begin{array}{c}\text { Oxidative decarboxylation of } \\
\text { 4-methyl-2-oxopentanoate, } \\
\text { 3-methyl-2-oxopentanoate, and } \\
\text { 3-methyl-2-oxobutanoate. Amino acid transport, } \\
\text { metabolism, and degradation. }\end{array}$ & $3.2 \pm 0.42$ \\
\hline 7 & Triose-phosphate isomerase & BXT84_02930, 241 & $\begin{array}{c}\text { Interconversion of dihydroxyacetone phosphate } \\
\text { and D-glyceraldehyde-3-phosphate. Energy } \\
\text { production and conversion. Carbon metabolism. } \\
\text { Glycolysis/gluconeogenesis. }\end{array}$ & $3.2 \pm 0.42$ \\
\hline 8 & $\begin{array}{l}\text { Branched-chain } \alpha \text {-keto acid } \\
\text { dehydrogenase subunit E2 }\end{array}$ & BXT84_00995, 436 & $\begin{array}{c}\text { Pyruvate/2-oxoglutarate dehydrogenase complex, } \\
\text { dihydrolipoamide acyltransferase (E2) component. } \\
\text { TCA cycle and valine, leucine, and isoleucine } \\
\text { degradation. Energy production and conversion. } \\
\text { Carbon metabolism. Amino acid transport, metabolism, } \\
\text { and degradation. }\end{array}$ & $3.1 \pm 0.40$ \\
\hline
\end{tabular}


Table 3. Cont

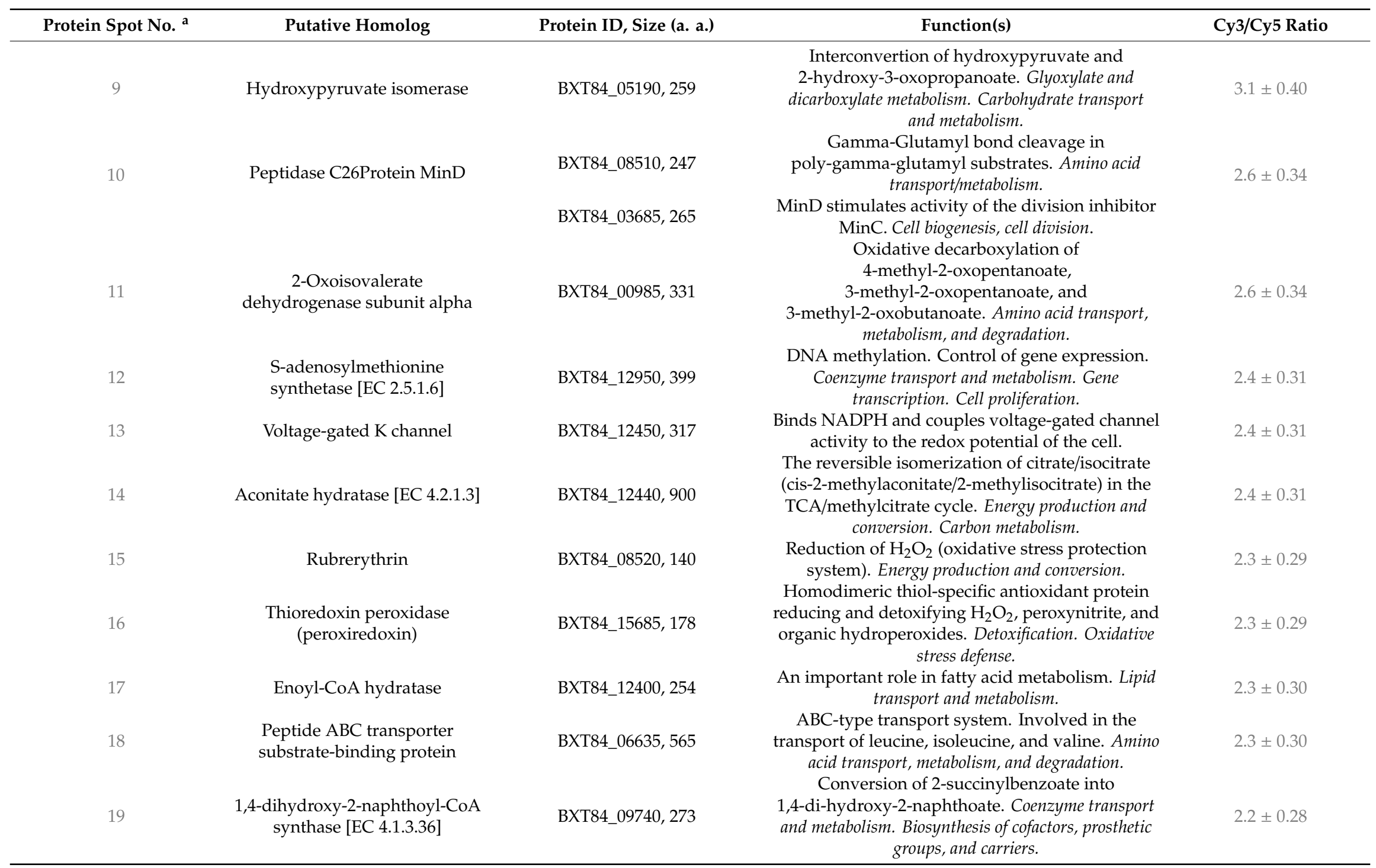


Table 3. Cont

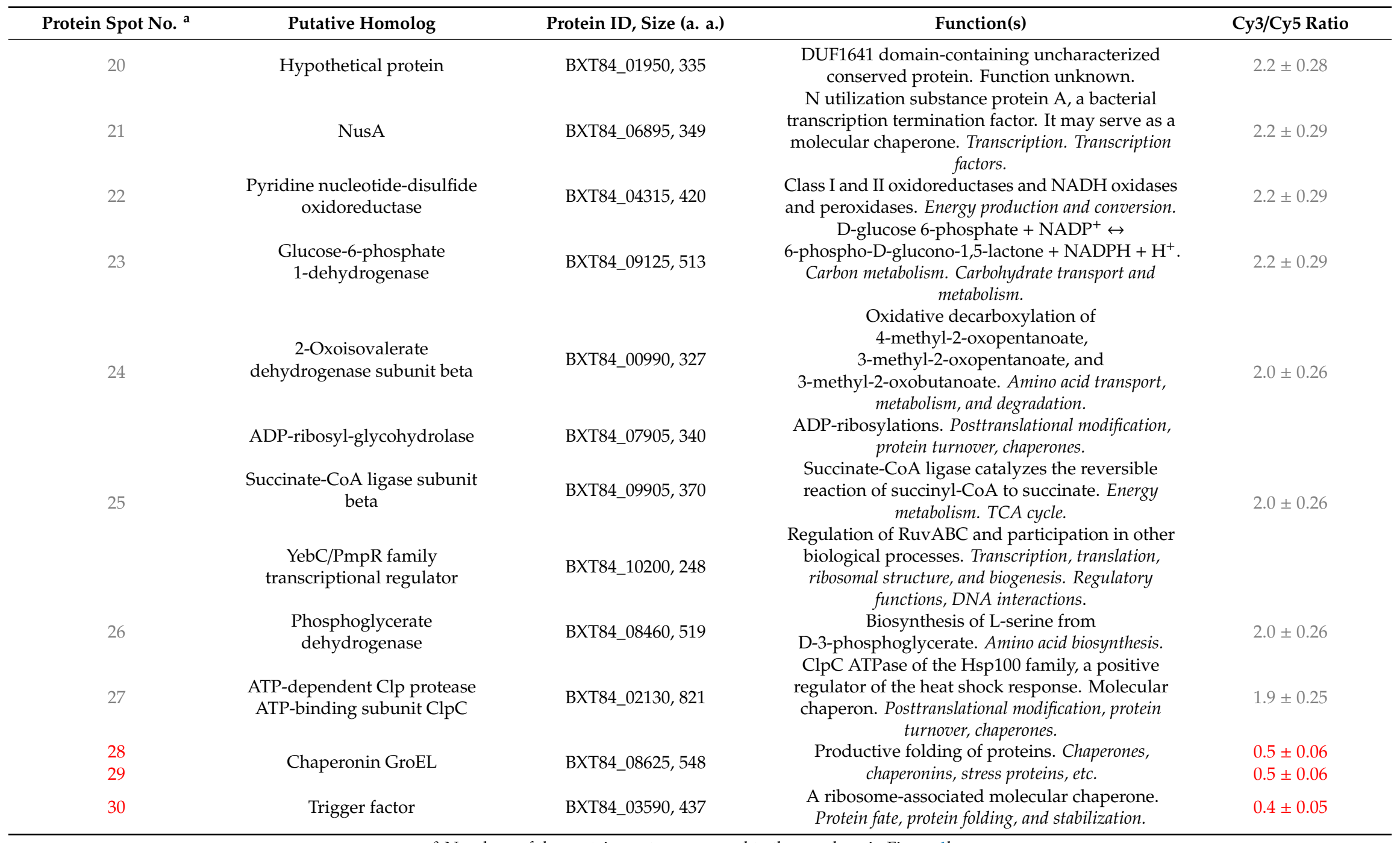

${ }^{a}$ Numbers of the protein spots correspond to the numbers in Figure $1 \mathrm{~b}$. 
Out of 33 proteins, which were differentially expressed in the $S b$. thermotolerans cells in response to the sulfide concentrate, only three proteins proved to be downregulated (Figure 1, Table 3).

According to a functional classification in clusters of orthologous groups (COGs), all regulated proteins were grouped into ten functional categories. More than half of the differentially expressed proteins were involved in carbohydrate and energy metabolism. Other proteins were assigned to the following functional categories: Genetic information processing, amino acid and protein metabolism, metabolism of vitamins and cofactors, and cellular processes (Figure 2).

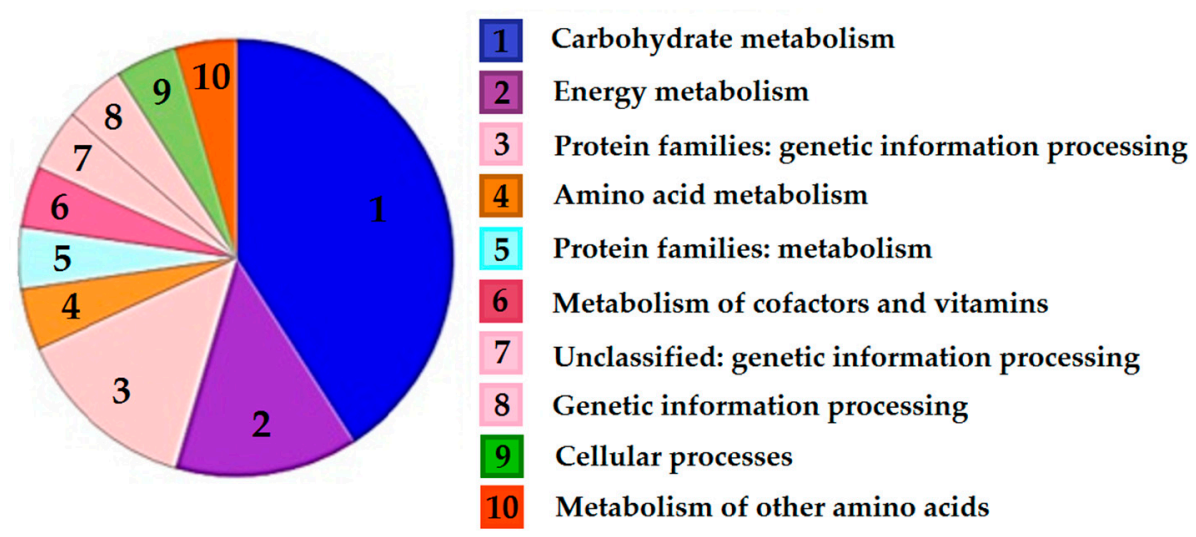

Figure 2. Results of the ortholog annotation of the proteins that were regulated in the Sb. thermotolerans cells in response to the pyrite-arsenopyrite concentrate, using KOALA (KEGG Orthology and Links Annotation) tools [47]. The pie chart shows the relative contribution of the functional categories of regulated proteins. The categories are numbered (1-10) and shown in different colors, according to KEGG color codes.

\subsubsection{Stress Response}

The stress response of $S b$. thermotolerans to the ore concentrate involved the regulation of the synthesis of chaperones and stress proteins. Thus, the ATP-binding ClpC subunit of the ATP-dependent Clp protease (a component of the Clp chaperone-protease complex, which is involved in protein degradation and disaggregation) was upregulated (Figure 1, Table 3). The ClpC subunit is required for growth at high temperatures (probably, it functions as a chaperone during heat shock) and for biofilm formation. It may act as a chaperone regulating CtsR activity [64] and participate in stress response to cadmium and copper ions [65]. In At. ferrivorans from the natural acid mine drainage environment (the Tinto River), the $\mathrm{ClpB}$ chaperone was one of the proteins that conferred arsenic resistance [66]. At the same time, the ribosome-associated molecular chaperone trigger factor (TF) was slightly downregulated in $S b$. thermotolerans (2.4-fold change). It was also downregulated in E. coli cells grown in the presence of excess $\mathrm{Zn}^{2+}$ [67] and only transiently produced during the growth-arrested phase in $\mathrm{Cd}^{2+}$-stressed E. coli cells [68].

In the sample of $\mathrm{Sb}$. thermotolerans $\mathrm{Kr} 1$ cells, which were grown in the medium containing the sulfide concentrate, one of the most abundant protein spots corresponded to the GroEL molecular chaperonin (5.3-fold change). The other two spots that were also identified as GroEL were slightly downregulated (2.1 times) (Figure 1, Table 3). Most likely, the observed changes in the location of the GroEL protein on the 2D map were due to the presence of post-translational modifications of this protein under conditions of the bacterial growth in the medium containing the sulfide concentrate. Previous studies have shown that the synthesis of GroEL is induced in Bacillus cereus cells exposed to silver ionic stress [69] and in E. coli cells in the presence of excess zinc in the culture medium [67]. In response to cadmium, GroEL is upregulated in Sphingomonas sp. [70] and Cd-tolerant Cupriavidus taiwanensis [71]. TF, GroEL, and one more chaperone (DnaK) have distinct but overlapping functions in assisting de novo folding. While the GroEL chaperone is essential under all growth conditions, TF and DnaK are not. The function of TF may be compensated by enhanced action of GroEL and DnaK [72]. 
In the case of $S b$. thermotolerans, we observed the upregulation of GroEL and downregulation of TF. We, therefore, suggest the possible role of the GroEL chaperonin in the tolerance mechanisms to heavy metals in $S b$. thermotolerans. Due to the probable modification, the GroEL chaperonin might be activated under the stressful conditions of growth.

Interestingly, the MBL fold metallo-hydrolase was the most upregulated protein (6.3 times) in response to the ore concentrate. This metal-related stress protein is highly upregulated in Staphylococcus cohnii, which is the probable mechanism for the survival of the organism under arsenic stress [73]. The substrate-binding component of the ABC-type thermophilic oligopeptide-binding transporter was also upregulated (2.3-fold) in $S b$. thermotolerans. This protein belongs to the type 2 periplasmic binding fold protein superfamily, participating in the transport of different metabolites: Amino acids, carbohydrates, ions, and polyamines. ABC-transporters also carry out the co-transport of metals in complex with different ligands: Amino acids, phosphates, peptides, and organic acids [74]. Nevertheless, no regulation of the proteins belonging to the specific metal(loid) resistance systems was found in response to toxic amounts of the ore concentrate in the growth medium.

Comparative proteomics revealed also the indicators of oxidative stress in response to the pyrite-arsenopyrite concentrate. Selenocysteine-containing peroxiredoxin PrxU (the antioxidant protein that reduces and detoxifies hydrogen peroxide, peroxynitrite, and organic hydroperoxides) was upregulated in the ore-grown Sb. thermotolerans cells (Figure 1, Table 3). In acidophilic bacteria, the AhpCF alkyl-hydroperoxidase/peroxiredoxin couple is suggested to be involved not only in the detoxification of organic peroxides but also in the degradation of $\mathrm{H}_{2} \mathrm{O}_{2}$ [37]. The upregulation of the synthesis of rubrerythrin (another scavenging enzyme of the oxidative stress defense system), reducing toxic hydrogen peroxide, was also observed in $S b$. thermotolerans. Rubrerythrin is encoded in several Leptospirillum spp. genomes and may function as $\mathrm{H}_{2} \mathrm{O}_{2}$ reductase [37].

Habitats of ACMs (for instance, acid mine drainage ecosystems) are characterized by low $\mathrm{pH}$ values and high contents of metal ions. Iron, copper, cobalt, nickel, and some other metals are known to increase the production of reactive oxygen species (ROS) [74]. Metal sulfides, such as pyrite and chalcopyrite, generate extracellular ROS upon exposure to acidic water. The recent study of the impact of $\mathrm{H}_{2} \mathrm{O}_{2}$ on At. ferrooxidans DSM $14882^{\mathrm{T}}$ has indicated that iron- or sulfur-grown cells show a higher sensitivity toward $\mathrm{H}_{2} \mathrm{O}_{2}$ than pyrite-grown cells. In total, 80 proteins that are potentially involved in general stress responses (such as chaperones, heat- or cold-shock proteins, and metal resistance proteins) and specific ROS defense mechanisms are regulated in the presence of $\mathrm{H}_{2} \mathrm{O}_{2}$, while 30 of these proteins are enhanced in pyrite biofilm cells [37]. The synergistic effect of $\mathrm{Li}^{+}$and $\mathrm{Co}^{2+}$, accumulated in the leachate in the simulated bioleaching system with $4.0 \%$ of $\mathrm{LiCoO}_{2}$ slurry, has been shown to cause the oxidative stress in the acidophilic microbial consortium including mainly $\mathrm{Sb}$. thermosulfidooxidans and L. ferriphilum [75]. Although the oxidative stress results in increased intracellular ROS, the addition of the exogenous glutathione (which acts as an antioxidant) increases the activities of GSH peroxidase and catalase to scavenge the excessive intracellular ROS, and this results in improved bioleaching of $\mathrm{LiCO}_{2}$ by the community [75].

We have previously shown that the genome of Sb. thermotolerans Kr1 encodes glutathione (GSH) peroxidase, which reduces hydroperoxides by glutathione, while no other Sulfobacillus species harbor this enzyme. The GSH peroxidase activity of $S b$. thermotolerans $\mathrm{Kr} 1$ is dependent on the aeration mode, showing higher values under conditions of intense aeration [16]. As mentioned above, arsenite $\left(\mathrm{As}^{3+}\right.$ ) reached high ambient concentrations (up to $30 \mathrm{mM}$ ) during the $S b$. thermotolerans growth in the presence of the ore concentrate. Although $\mathrm{As}^{3+}$ could potentially deplete intracellular glutathione, according to the known mechanism of its action [76], the level of the GSH peroxidase synthesis did not change in our experiments. However, similarly to an increase in the GSH peroxidase activity under oxidative stress [16], ROS could affect the activity of this antioxidant enzyme and, therefore, the intracellular pool of glutathione. 


\subsubsection{Metabolic Reorganization}

The data obtained in this study revealed the enforcement of metabolic pathways in response to the high content of the sulfide concentrate. An increase in the biosynthesis levels of the enzymes involved in the carbohydrate and energy metabolism, amino acid biosynthesis/degradation pathways, and the TCA cycle was observed (Table 3). Figure 3a shows the upregulation of several enzymes that are involved in the TCA cycle and carbohydrate catabolism, as well as one enzyme, which is common for the Embden-Meyerhof-Parnas pathway, gluconeogenesis, and Calvin cycle.

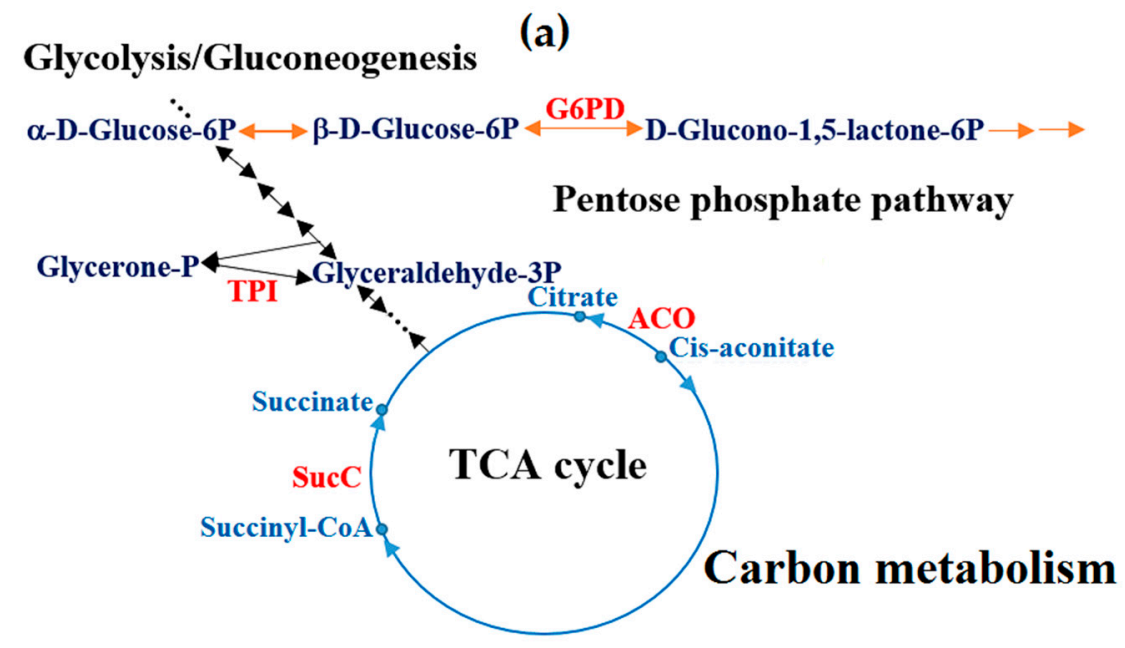

(b)

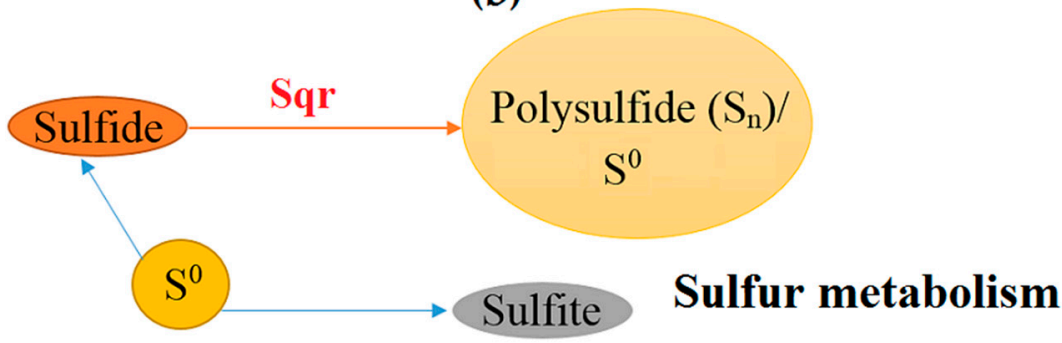

Figure 3. Reinforcement of (a) carbon and (b) sulfur metabolism pathways in Sb. thermotolerans in response to the gold-bearing pyrite-arsenopyrite concentrate. TPI: Triosephosphate isomerase [EC 5.3.1.1]; G6PD: Glucose-6-phosphate 1-dehydrogenase [EC 1.1.1.49 1.1.1.363]; ACO: Aconitate hydratase [EC 4.2.1.3]; SucC: Succinyl-CoA synthetase beta subunit [EC 6.2.1.5]; Sqr: Sulfide:quinone oxidoreductase [EC 1.8.5.4]. Substrates, intermediates, and products are indicated in blue (a) and upregulated enzymes are indicated in red $(\mathbf{a}, \mathbf{b})$.

The differential regulation of the proteins involved in energy metabolism was also found. For instance, 1,4-dihydroxy-2-naphthoyl-CoA (catalyzes the main step in menaquinone biosynthesis, electron transport) and two different FAD-dependent pyridine nucleotide-disulfide oxidoreductases were upregulated in response to the sulfide concentrate. Among all regulated proteins, an increase in the synthesis of the sulfide:quinone oxidoreductase (SQR) was one of the highest (5.8 times) (Table 3). This enzyme (eight copies in the genome of $S b$. thermotolerans Kr1) catalyzes the transformation of hydrogen sulfide to polysulfide in the sulfur metabolism pathway (Figure 3b). Even a higher level of expression (10-fold) of this enzyme in Sb. thermotolerans cells that were grown in the presence of high amounts of zinc in the medium, which contained no sulfur substrates (our unpublished data), suggests a possible role of SQR in the metal resistance mechanism, in addition to its role in the sulfur metabolism. A hypothetical protein (BXT84_01950, Table 3), which is encoded by the gene located upstream of the SQR gene (BXT84_01945) in the Sb. thermotolerans genome, was also upregulated (2.2-fold). Its function remains unknown. 
The S-adenosylmethionine synthetase was also shown to be regulated in Sb. thermotolerans. This enzyme was represented by two protein spots both of which were upregulated (2.4- and 5.0-fold). Overexpression of the S-adenosylmethionine synthetase that plays a pivotal role in the central metabolism of all organisms is expected to produce increased levels of S-adenosylmethionine. The latter is a precursor for the synthesis of polyamines, including spermidine, which is involved in thiol metabolism, and a metabolite in the trans-sulfuration pathway to cysteine. S-adenosylmethionine is the primary methyl group donor in methylation reactions; it regulates cell signaling, gene expression, and metabolic pathways [77]. The upregulation of this enzyme (3.7-fold) has been found in the cells of At. caldus (another member of communities of ACMs) grown in the presence of $200 \mathrm{mM} \mathrm{ZnSO}_{4}$ [28]. In the cells of $\mathrm{Sb}^{3+}$-resistant clinical isolates of Leishmania panamensis, the S-adenosylmethionine synthetase is upregulated exclusively, playing a central role in the upstream synthesis of precursors of trypanothione (a key molecule involved in the Sb-resistance in Leishmania parasites), indicating the importance of thiol metabolism in resistance to the antimony in Leishmania [78]. In plants, the S-adenosylmethionine synthetase plays an essential role in response to stress, including metal stress $[79,80]$.

Several enzymes participating in amino acid degradation in $S b$. thermotolerans were also upregulated (Figure 4, Table 3). They included two subunits of the 2-oxoisovalerate dehydrogenase enzyme, which is involved in valine, leucine, and isoleucine degradation, as well as propionate metabolism. The upregulation of this protein has been found in Sphingomonas sp. cells in response to $\mathrm{Cd}^{2+}$ [70]. Other enzymes of amino acid metabolism were also upregulated, including cysteine desulfurase (5.4-fold; it catalyzes the removal of elemental sulfur and selenium atoms from L-cysteine, L-cystine, L-selenocysteine, and L-selenocystine to produce L-alanine) and D-3-phosphoglycerate dehydrogenase (2-fold). Amino acids are known to be potential ligands for heavy metals and contribute to tolerance and detoxification [66].

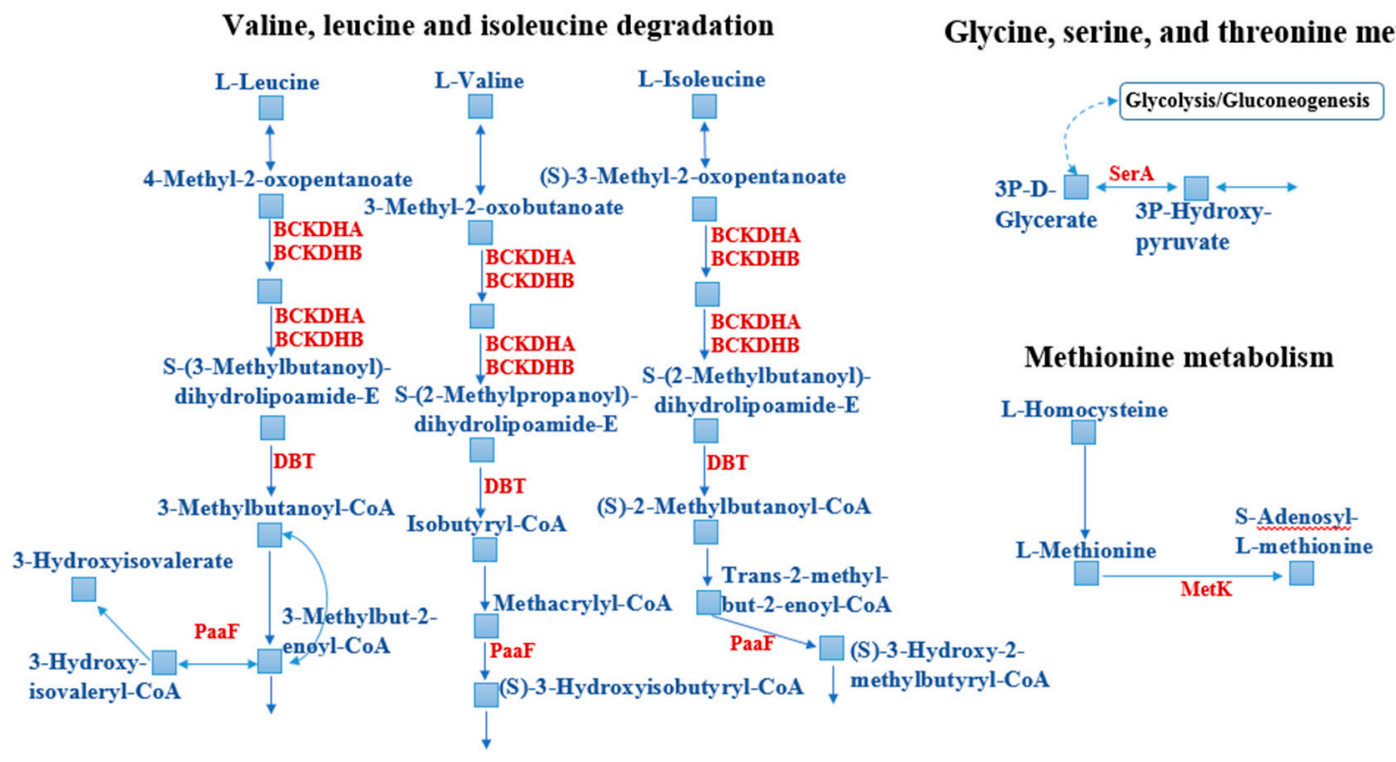

Figure 4. Upregulation of the components of the amino acid metabolism in Sb. thermotolerans in response to the gold-bearing pyrite-arsenopyrite concentrate. PaaF: Enoyl-CoA hydratase [EC 4.2.1.17]; DBT: 2-Oxoisovalerate dehydrogenase E2 component (dihydrolipoyl transacylase) [EC 2.3.1.168]; BCKDHB: 2-Oxoisovalerate dehydrogenase E1 component beta subunit [EC 1.2.4.4]; BCKDHA: 2-Oxoisovalerate dehydrogenase E1 component alpha subunit [EC 1.2.4.4]; MetK: S-adenosylmethionine synthetase [EC 2.5.1.6]; SerA: D-3-phosphoglycerate dehydrogenase/2-oxoglutarate reductase [EC 1.1.1.95 1.1.1.399]. Substrates, intermediates, and products are indicated in blue and upregulated enzymes are indicated in red.

The general response of $S b$. thermotolerans $\mathrm{Kr} 1$ cells involved also changes in the transcription, translation, cell biogenesis, coenzyme transport and metabolism, as well as the metabolism of fatty 
acids and secondary metabolites (Figure 2, Table 3). For instance, the YebC/PmpR family DNA-binding transcriptional regulator was found to be upregulated (2-fold) in response to the ore concentrate. The YebC family regulator proteins are widespread and conserved in many bacteria. YebC may serve as a multi-functional transcription regulator; it is predicted to regulate the resolvase complex RuvABC, most likely the RuvC subunit, and may participate in other biological processes [81]. The YebC protein is responsible for the quorum-sensing (QS) and virulence in Edwardsiella piscicida, the negative regulation of the QS response regulator in Pseudomonas aeruginosa, and, probably, proteolysis in Lactobacillus [82]. In the metal-tolerant bacterium Alishewanella sp., the YebC family protein RuvR is involved in $\mathrm{Cr}^{6+}$, $\mathrm{As}^{3+}, \mathrm{Sb}^{3+}$, and $\mathrm{Cd}^{2+}$ resistance [83]. The NusA protein that participates in transcriptional elongation, termination, anti-termination, as well as cold shock and stress-induced mutagenesis [84], was also upregulated (2.2-fold) in response to the arsenic-rich sulfide concentrate. NusA is suggested to serve as a molecular chaperone in addition to its functions as a transcription factor [84]. In the case of $S b$. thermotolerans, the upregulation of this protein could also be associated with the stress effect of toxic compounds in the medium of growth.

Thus, on the basis of differential proteomic analysis, a total of 33 proteins were regulated in $S b$. thermotolerans in response to the high-arsenic sulfide concentrate. Although higher numbers of regulated proteins may be expected under metal(loid) stress [23], the results of our study are in agreement with the previously reported proteomic data for other acidophiles. For instance, in At. ferrooxidans, At. caldus, Am. ferrooxidans, and F. acidarmanus, 7-21 proteins were upregulated and 1-22 proteins were downregulated in response to zinc, arsenic, copper, and uranium stress $[24,26,28,85]$.

It should be mentioned that mainly planktonic late-exponential vegetative cells (already detached or not yet attached to the mineral particles) and single forespores ( 1-1.5\%) from the liquid phase, which contained iron, arsenic, and other dissolved elements, were analyzed in this study. According to other proteomic reports, differences in the proteomic responses of the planktonic and sessile (biofilm) cell subpopulations of At. ferrooxidans, oxidizing pyrite, have been revealed [37,41]. Therefore, the accumulation of elements by sessile cells of $\mathrm{Sb}$. thermotolerans and their proteomic response could vary from those of the planktonic cell population.

Overall, the results of our research imply that changes in the protein expression in $\mathrm{Sb}$. thermotolerans cells were closely related to the accumulation of the toxic arsenic. Several proteins that seem to confer resistance to arsenic in other microorganisms $[66,73,76,83,84]$, but do not belong to any specific arsenic-resistance systems, were shown to be upregulated in this acidophilic bacterium. In other studied acidophiles, responses to arsenic are associated with specific arsenic resistance proteins $[31,33,34]$. The latter, as well as the proteins involved in phosphate metabolism, protection from reactive oxygen species, GSH metabolism, DNA synthesis and repair, protein synthesis, folding and refolding, are regulated in L. ferriphilum in response to the arsenic stress [33]. In acidophilic archaeon F. acidarmanus, the proteomic analysis has not detected increased expression of the ArsB pump; the proteomic response to arsenic involves a number of protein repair and modification enzymes, as well as metabolic and electron transport proteins [85]. However, few studies on the proteomic responses of acidophiles to arsenic have been reported in the literature $[33,85]$, and future proteomic research would be of interest to provide a better understanding of the molecular mechanisms for arsenic resistance in this microbial group.

It is noteworthy that according to our proteomic data on the metabolic reorganization, no pathways were inhibited in $\mathrm{Sb}$. thermotolerans in response to the high-arsenic sulfide concentrate. On the contrary, some pathways were reinforced, while iron oxidation rates remained rather high. These results suggest that the components of carbon, energy, and amino acid metabolism, as well as those of stress response systems, may be essential in the resistance mechanisms of $S b$. thermotolerans to the toxic effects of the gold-containing pyrite-arsenopyrite concentrates. The efficient iron oxidation and reinforcement of catabolic pathways indicate the advantages of the mixotrophic lifestyle of $\mathrm{Sb}$. thermotolerans during adaptation to stress factors. This trophic strategy makes it possible to meet the increased metabolic demands of the bacterium under adverse conditions and enhance its growth. Due to the utilization 
of organic compounds, $S b$. thermotolerans may also play an essential role in the detoxification of the environment for chemolithoautotrophs (removal of microbial metabolites and lysis products) in acidophilic microbial communities exposed to metal(loid) stress.

\section{Conclusions}

The results of our research provide first insights into the mechanisms of resistance to the gold-bearing arsenopyrite concentrates in the genus Sulfobacillus. It was shown that:

- Sb. thermotolerans rapidly adapted to the toxic amount of the high-arsenic gold-bearing sulfide concentrate and proved to be among the most As-tolerant organisms known to date;

- although the cellular adsorption and intracellular accumulation of metal(loid)s occurred to high levels, the bacterium retained its growth and efficient substrate oxidation;

- in total, 30 upregulated proteins were involved in the response to the toxic content of the sulfide concentrate in the growth medium, and only three proteins, which, however, did not affect the vital activity of the preliminarily nonadapted $S b$. thermotolerans cells, were downregulated;

- $\quad S b$. thermotolerans cells responded to adverse conditions by metabolic changes, including reinforcement of pathways of constructive and energy metabolism, and by activation of defense systems against unfavorable factors. At the same time, no specific metal-resistance components were regulated in response to metal(loid)s accumulated in the culture medium and by the cells;

- proteins of the stress response, such as the metal-related stress protein MBL fold metallo-hydrolase and GroEL chaperonin, probably, played crucial roles in the tolerance to the high-arsenic sulfide ore concentrate and arsenic, in particular;

- the markedly upregulated sulfide:quinone oxidoreductase, cysteine desulfurase, and S-adenosylmethionine synthetase were other main contributors to the bacterial response. Apart from the enzymatic function in sulfur metabolism, sulfide:quinone oxidoreductase potentially fulfilled the second function of a resistance-conferring protein in Sb. thermotolerans.

This study and previous works indicate a high resistance potential of Sb. thermotolerans, which is of interest to both the fundamental science and industrial applications. Our results may open up new perspectives on the investigation of the roles of certain proteins in the tolerance mechanisms to different metal(loid)s in Sulfobacillus bacteria and other biomining acidophiles.

Supplementary Materials: The following are available online at http://www.mdpi.com/2076-2607/8/7/1076/s1. Figure S1: Growth of Sb. thermotolerans $\mathrm{Kr1}$ and iron oxidation under different cultivation conditions: (a) In the medium containing ferrous iron (control); in the presence of 10 (b), 20 (c), and $30 \mathrm{~g} / \mathrm{L}$ (d) of the gold-containing pyrite-arsenopyrite concentrate. Arrows $(\mathbf{b}, \mathbf{d})$ indicate parameters of the samples used in the experiments.

Author Contributions: Conceptualization, A.P.; methodology, A.P., D.M., and O.P.; validation, A.P., D.M., and O.P.; formal analysis, investigation, and resources, A.P., D.M., and O.P.; data curation, A.P., D.M., and O.P.; writing—original draft preparation, A.P.; writing—review and editing, A.P., D.M., and O.P.; visualization, A.P., D.M., and O.P.; supervision, A.P.; project administration, A.P.; funding acquisition, A.P. All authors have read and agreed to the published version of the manuscript.

Funding: This research was funded by the Ministry of Science and Higher Education of the Russian Federation.

Acknowledgments: We thank the Center for Precision Genome Editing and Genetic Technologies for Biomedicine, the Federal Research and Clinical Center of Physical-Chemical Medicine of Federal Medical Biological Agency for the equipment for mass spectrometric analysis.

Conflicts of Interest: The authors declare no conflict of interest.

\section{References}

1. Kaksonen, A.H.; Boxall, N.J.; Gumulya, Y.; Khaleque, H.N.; Morris, C.; Bohu, T.; Cheng, K.Y.; Usher, K.M.; Lakaniemi, A.-M. Recent progress in biohydrometallurgy and microbial characterisation. Hydrometallurgy 2018, 180, 7-25. [CrossRef]

2. Rawlings, D.E.; Johnson, D.B. The microbiology of biomining: Development and optimization of mineral-oxidizing microbial consortia. Microbiology 2007, 153, 315-324. [CrossRef] 
3. Bond, P.L.; Druschel, G.K.; Banfield, J.F. Comparison of acid mine drainage microbial communities in physically and geochemically distinct ecosystems. Appl. Environ. Microbiol. 2000, 66, 4962-4971. [CrossRef]

4. d'Hugues, P.; Joulian, C.; Spolaore, P.; Michel, C.; Garrido, F.; Morin, D. Continuous bioleaching of a pyrite concentrate in stirred reactors: Population dynamics and exopolysaccharide production vs. bioleaching performance. Hydrometallurgy 2008, 94, 34-41. [CrossRef]

5. Dopson, M.; Lindström, E.B. Analysis of community composition during moderately thermophilic bioleaching of pyrite, arsenical pyrite, and chalcopyrite. Microb. Ecol. 2004, 48, 19-28. [CrossRef] [PubMed]

6. Bogdanova, T.I.; Tsaplina, I.A.; Kondrat'eva, T.F.; Duda, V.I.; Suzina, N.E.; Melamud, V.S.; Tourova, T.P.; Karavaiko, G.I. Sulfobacillus thermotolerans sp. nov., a thermotolerant, chemolithotrophic bacterium. Int. J. Syst. Evol. Microbiol. 2006, 56, 1039-1042. [CrossRef] [PubMed]

7. Tan, G.L.; Shu, W.S.; Hallberg, K.B.; Li, F.; Lan, C.Y.; Zhou, W.H.; Huang, L.N. Culturable and molecular phylogenetic diversity of microorganisms in an open-dumped, extremely acidic $\mathrm{Pb} / \mathrm{Zn}$ mine tailings. Extremophiles 2008, 12, 657-664. [CrossRef]

8. Tsaplina, I.A.; Krasil'nikova, E.N.; Zhuravleva, A.E.; Egorova, M.A.; Zakharchuk, L.M.; Suzina, N.E.; Bogdanova, T.I.; Kondrat'eva, T.F. Phenotypic properties of Sulfobacillus thermotolerans: Comparative aspects. Microbiology 2008, 77, 654-664. [CrossRef]

9. Fomchenko, N.V.; Muravyov, M.I. Two-step biohydrometallurgical technology of copper-zinc concentrate processing as an opportunity to reduce negative impacts on the environment. J. Environ. Manag. 2018, 226, 270-277. [CrossRef]

10. Muravyov, M.; Panyushkina, A. Distinct roles of acidophiles in complete oxidation of high-sulfur ferric leach product of zinc sulfide concentrate. Microorganisms 2020, 8, 386. [CrossRef]

11. Hao, C.; Wang, L.; Dong, H.; Zhang, H. Succession of acidophilic bacterial community during bio-oxidation of refractory gold-containing sulfides. Geomicrobiol. J. 2010, 27, 683-691. [CrossRef]

12. Tsaplina, I.A.; Panyushkina, A.E.; Melamud, V.S.; Grigor'eva, N.V.; Kondrat'eva, T.F. Leaching of pyrite-arsenopyrite concentrate in bioreactors during continuous cultivation of a thermoacidophilic microbial community. Microbiology 2014, 83, 568-576. [CrossRef]

13. Bulaev, A.; Belyi, A.; Panyushkina, A.; Solopova, N.; Pivovarova, T. Microbial population of industrial biooxidation reactors. Solid State Phenom. 2017, 262, 48-52. [CrossRef]

14. Tsaplina, I.A.; Zhuravleva, A.E.; Egorova, M.A.; Bogdanova, T.I.; Krasil'nikova, E.N.; Zakharchuk, L.M.; Kondrat'eva, T.F. Response to oxygen limitation in bacteria of the genus Sulfobacillus. Microbiology 2010, 79 , 13-22. [CrossRef]

15. Panyushkina, A.E. Metabolic potential of Sulfobacillus thermotolerans: Pathways for assimilation of nitrogen compounds and the possibility of lithotrophic growth in the presence of molecular hydrogen. Microbiology 2019, 13, 759-763. [CrossRef]

16. Panyushkina, A.E.; Babenko, V.V.; Nikitina, A.S.; Selezneva, O.V.; Tsaplina, I.A.; Letarova, M.A.; Kostryukova, E.S.; Letarov, A.V. Sulfobacillus thermotolerans: New insights into resistance and metabolic capacities of acidophilic chemolithotrophs. Sci. Rep. 2019, 9, 15069. [CrossRef]

17. Tuffin, I.M.; Hector, S.B.; Deane, S.M.; Rawlings, D.E. Resistance determinants of a highly arsenic-resistant strain of Leptospirillum ferriphilum isolated from a commercial biooxidation tank. Appl. Environ. Microbiol. 2006, 72, 2247-2253. [CrossRef]

18. Navarro, C.A.; von Bernath, D.; Jerez, C.A. Heavy metal resistance strategies of acidophilic bacteria and their acquisition: Importance for biomining and bioremediation. Biol. Res. 2013, 46, 363-371. [CrossRef] [PubMed]

19. Orell, A.; Navarro, C.A.; Arancibia, R.; Mobarec, J.C.; Jerez, C.A. Life in blue: Copper resistance mechanisms of bacteria and archaea used in industrial biomining of minerals. Biotechnol. Adv. 2010, 28, 839-848. [CrossRef]

20. Orellana, L.H.; Jerez, C.A. A genomic island provides Acidithiobacillus ferrooxidans ATCC 53993 additional copper resistance: A possible competitive advantage. Appl. Microbiol. Biotechnol. 2011, 92, 761-767. [CrossRef]

21. Salazar, C.; Acosta, M.; Galleguillos, P.; Shmaryahu, A.; Quatrini, R.; Holmes, D.S.; Demergasso, C. Analysis of gene expression in response to copper stress in Acidithiobacillus ferrooxidans strain D2, isolated from a copper bioleaching operation. Adv. Mat. Res. 2013, 825, 157-161. [CrossRef] 
22. Wu, X.; Zhang, Z.; Liu, L.; Deng, F.; Liu, X.; Qiu, G. Metal resistance-related genes are differently expressed in response to copper and zinc ion in six Acidithiobacillus ferrooxidans strains. Curr. Microbiol. 2014, 69, 775-784. [CrossRef] [PubMed]

23. Almárcegui, R.J.; Navarro, C.A.; Paradela, A.; Albar, J.P.; von Bernath, D.; Jerez, C.A. New copper resistance determinants in the extremophile Acidithiobacillus ferrooxidans: A quantitative proteomic analysis. J. Proteome Res. 2014, 13, 946-960. [CrossRef] [PubMed]

24. Dekker, L.; Arsène-Ploetze, F.; Santini, J.M. Comparative proteomics of Acidithiobacillus ferrooxidans grown in the presence and absence of uranium. Res. Microbiol. 2016, 167, 234-239. [CrossRef] [PubMed]

25. Fatemi, F.; Miri, S.; Jahani, S. Effect of metal sulfide pulp density on gene expression of electron transporters in Acidithiobacillus sp. FJ2. Arch. Microbiol. 2017, 199, 521-530. [CrossRef]

26. Baker-Austin, C.; Dopson, M.; Wexler, M.; Sawers, R.G.; Bond, P.L. Molecular insight into extreme copper resistance in the extremophilic archaeon 'Ferroplasma acidarmanus' Fer1. Microbiology 2005, 151, 2637-2646. [CrossRef] [PubMed]

27. Orell, A.; Remonsellez, F.; Arancibia, R.; Jerez, C.A. Molecular characterization of copper and cadmium resistance determinants in the biomining thermoacidophilic archaeon Sulfolobus metallicus. Archaea 2013, 2013, 289236. [CrossRef]

28. Mangold, S.; Potrykus, J.; Björn, E.; Lövgren, L.; Dopson, M. Extreme zinc tolerance in acidophilic microorganisms from the bacterial and archaeal domains. Extremophiles 2013, 17, 75-85. [CrossRef]

29. Martínez-Bussenius, C.; Navarro, C.A.; Jerez, C.A. Microbial copper resistance: Importance in biohydrometallurgy. Microb. Biotechnol. 2017, 10, 279-295. [CrossRef]

30. Soto, D.F.; Recalde, A.; Orell, A.; Albers, S.-V.; Paradela, A.; Navarro, C.A.; Jerez, C.A. Global effect of the lack of inorganic polyphosphate in the extremophilic archaeon Sulfolobus solfataricus: A proteomic approach. J. Proteomics. 2019, 191, 143-152. [CrossRef]

31. Dopson, M.; Holmes, D. Metal resistance in acidophilic microorganisms and its significance for biotechnologies. Appl. Microbiol. Biotechnol. 2014, 98, 8133-8144. [CrossRef]

32. Dopson, M.; Ossandon, F.J.; Lövgren, L.; Holmes, D.S. Metal resistance or tolerance? Acidophiles confront high metal loads via both abiotic and biotic mechanisms. Front. Microbiol. 2014, 5, 157. [CrossRef] [PubMed]

33. Li, B.; Lin, J.; Mi, S.; Lin, J. Arsenic resistance operon structure in Leptospirillum ferriphilum and proteomic response to arsenic stress. Bioresour. Technol. 2010, 101, 9811-9814. [CrossRef]

34. Jiang, H.; Liang, Y.; Yin, H.; Xiao, Y.; Guo, X.; Xu, Y.; Hu, Q.; Liu, H.; Liu, X. Effects of arsenite resistance on the growth and functional gene expression of Leptospirillum ferriphilum and Acidithiobacillus thiooxidans in pure culture and coculture. BioMed Res. Int. 2015, 2015, 203197. [CrossRef] [PubMed]

35. Ramírez, P.; Guiliani, N.; Valenzuela, L.; Beard, S.; Jerez, C.A. Differential protein expression during growth of Acidithiobacillus ferrooxidans on ferrous iron, sulfur compounds, or metal sulfides. Appl. Environ. Microbiol. 2004, 70, 4491-4498. [CrossRef] [PubMed]

36. Felício, A.P.; Oliveira, E.; Odena, M.A.; Garcia, O., Jr.; Bertolini, M.C.; Ferraz, L.F.C.; Ottoboni, L.M.M.; Novo, M.T.M. Differential proteomic analysis of Acidithiobacillus ferrooxidans cells maintained in contact with bornite or chalcopyrite: Proteins involved with the early bacterial response. Process Biochem. 2011, 46, 770-776. [CrossRef]

37. Bellenberg, S.; Huynh, D.; Poetsch, A.; Sand, W.; Vera, M. Proteomics reveal enhanced oxidative stress responses and metabolic adaptation in Acidithiobacillus ferrooxidans biofilm cells on pyrite. Front. Microbiol. 2019, 10, 592. [CrossRef]

38. Carlos, C.; Reis, F.C.; Vicentini, R.; Madureira, D.J.; Ottoboni, L.M.M. The rus operon genes are differentially regulated when Acidithiobacillus ferrooxidans LR is kept in contact with metal sulfides. Curr. Microbiol. 2008, 57, 375-380. [CrossRef]

39. Christel, S.; Herold, M.; Bellenberg, S.; Hajjami, M.E.; Buetti-Dinh, A.; Pivkin, I.V.; Sand, W.; Wilmes, P.; Poetsch, A.; Dopson, M. Multi-omics reveals the lifestyle of the acidophilic, mineral-oxidizing model species Leptospirillum ferriphilum ${ }^{\mathrm{T}}$. Appl. Environ. Microbiol. 2018, 84, e02091-17. [CrossRef]

40. Sand, W.; Gehrke, T. Extracellular polymeric substances mediate bioleaching/biocorrosion via interfacial processes involving iron(III) ions and acidophilic bacteria. Res. Microbiol. 2006, 157, 49-56. [CrossRef]

41. Vera, M.; Krok, B.; Bellenberg, S.; Sand, W.; Poetsch, A. Shotgun proteomics study of early biofilm formation process of Acidithiobacillus ferrooxidans ATCC 23270 on pyrite. Proteomics 2013, 13, 1133-1144. [CrossRef] [PubMed] 
42. Belnap, C.P.; Pan, C.; VerBerkmoes, N.C.; Power, M.E.; Samatova, N.F.; Carver, R.L.; Hettich, R.L.; Banfield, J.F. Cultivation and quantitative proteomic analyses of acidophilic microbial communities. ISME J. 2010, 4, 520-530. [CrossRef] [PubMed]

43. Wilmes, P.; Bowen, B.P.; Thomas, B.C.; Mueller, R.S.; Denef, V.J.; VerBerkmoes, N.C.; Hettich, R.L.; Northen, T.R.; Banfield, J.F. Metabolome-proteome differentiation coupled to microbial divergence. MBio 2010, 1, e00246-10. [CrossRef] [PubMed]

44. Mosier, A.C.; Li, Z.; Thomas, B.C.; Hettich, R.L.; Pan, C.; Banfield, J.F. Elevated temperature alters proteomic responses of individual organisms within a biofilm community. ISME J. 2015, 9, 180-194. [CrossRef]

45. Shevchenko, A.; Wilm, M.; Vorm, O.; Mann, M. Mass spectrometric sequencing of proteins from silver-stained polyacrylamide gels. Anal. Chem. 1996, 68, 850-858. [CrossRef]

46. Jensen, O.N.; Wilm, M.; Shevchenko, A.; Mann, M. Peptide sequencing of 2-DE gel-isolated proteins by nanoelectrospray tandem mass spectrometry. Methods Mol. Biol. 1999, 112, 571-588. [CrossRef] [PubMed]

47. Kanehisa, M.; Sato, Y.; Kawashima, M.; Furumichi, M.; Tanabe, M. KEGG as a reference resource for gene and protein annotation. Nucleic Acids Res. 2016, 44, D457-462. [CrossRef] [PubMed]

48. Melamud, V.S.; Pivovarova, T.A.; Kondrat'eva, T.F.; Karavaiko, G.I. Study of oxidation by bacteria of a difficult-to-dress gold-containing pyrite-arsenopyrite concentrate under moderately thermophilic conditions. Appl. Biochem. Microbiol. 1999, 35, 161-167.

49. Goyal, N.; Jain, S.C.; Banerjee, U.C. Comparative studies on the microbial adsorption of heavy metals. Adv. Environ. Res. 2003, 7, 311-319. [CrossRef]

50. Pagani, M.A.; Casamayor, A.; Serrano, R.; Atrian, S.; Ariño, J. Disruption of iron homeostasis in Saccharomyces cerevisiae by high zinc levels: A genome-wide study. Mol. Microbiol. 2007, 65, 521-537. [CrossRef]

51. Watling, H.R.; Perrot, F.A.; Shiers, D.W. Comparison of selected characteristics of Sulfobacillus species and review of their occurrence in acidic and bioleaching environments. Hydrometallurgy 2008, 93, 57-65. [CrossRef]

52. Dave, S.R.; Gupta, K.H.; Tipre, D.R. Characterization of arsenic resistant and arsenopyrite oxidizing Acidithiobacillus ferrooxidans from Hutti gold leachate and effluents. Bioresour. Technol. 2008, 99, 7514-7520. [CrossRef]

53. Casas-Flores, S.; Gómez-Rodríguez, E.Y.; García-Meza, J.V. Community of thermoacidophilic and arsenic resistant microorganisms isolated from a deep profile of mine heaps. AMB Express 2015, 5, 54. [CrossRef] [PubMed]

54. Kotze, A.A.; Tuffin, I.M.; Deane, S.M.; Rawlings, D.E. Cloning and characterization of the chromosomal arsenic resistance genes from Acidithiobacillus caldus and enhanced arsenic resistance on conjugal transfer of ars genes located on transposon TnAtcArs. Microbiology 2006, 152, 3551-3560. [CrossRef] [PubMed]

55. Dopson, M.; Baker-Austin, C.; Koppineedi, P.R.; Bond, P.L. Growth in sulfidic mineral environments: Metal resistance mechanisms in acidophilic micro-organisms. Microbiology 2003, 149, 1959-1970. [CrossRef]

56. Banerjee, S.; Datta, S.; Chattyopadhyay, D.; Sarkar, P. Arsenic accumulating and transforming bacteria isolated from contaminated soil for potential use in bioremediation. J. Environ. Sci. Health A. Tox. Hazard. Subst. Environ. Eng. 2011, 46, 1736-1747. [CrossRef]

57. Yin, X.X.; Wang, L.H.; Bai, R.; Huang, H.; Sun, G.X. Accumulation and transformation of arsenic in the blue-green alga Synechocystis sp. PCC6803. Water Air Soil Pollut. 2012, 223, 1183-1190. [CrossRef]

58. Mayzel, B.; Aizenberg, J.; Ilan, M. The elemental composition of Demospongiae from the Red Sea, Gulf of Aqaba. PLoS ONE 2014, 9, e95775. [CrossRef]

59. Keren, R.; Mayzel, B.; Lavy, A.; Polishchuk, I.; Levy, D.; Fakra, S.C.; Pokroy, B.; Ilan, M. Sponge-associated bacteria mineralize arsenic and barium on intracellular vesicles. Nat. Commun. 2017, 8, 14393. [CrossRef]

60. Dorian, A.B.H.; Landy, I.R.B.; Enrique, D.-P.; Luis, F.-L. Zinc and lead biosorption by Delftia tsuruhatensis: A bacterial strain resistant to metals isolated from mine tailings. J. Water Resour. Prot. 2012, 4, 207-216. [CrossRef]

61. Celaya, R.J.; Noriega, J.A.; Yeomans, J.H.; Ortega, L.J.; Ruiz-Manríquez, A. Biosorption of Zn(II) by Thiobacillus ferrooxidans. Bioprocess Eng. 2000, 22, 539-542. [CrossRef]

62. Liu, H.-L.; Chen, B.-Y.; Lan, Y.-W.; Cheng, Y.-C. Biosorption of Zn(II) and Cu(II) by the indigenous Thiobacillus thiooxidans. Chem. Eng. J. 2004, 97, 195-201. [CrossRef] 
63. Aston, J.E.; Apel, W.A.; Lee, B.D.; Peyton, B.M. Effects of cell condition, pH, and temperature on lead, zinc, and copper sorption to Acidithiobacillus caldus strain BC13. J. Hazard. Mater. 2010, 184, 34-41. [CrossRef] [PubMed]

64. Frees, D.; Chastanet, A.; Qazi, S.; Soerensen, K.; Hill, P.; Msadek, T.; Ingmer, H. Clp ATPases are required for stress tolerance, intracellular replication and biofilm formation in Staphylococcus aureus. Mol. Microbiol. 2004, 54, 1445-1462. [CrossRef] [PubMed]

65. Sitthisak, S.; Kitti, T.; Boonyonying, K.; Wozniak, D.; Devreese, B.; Mongkolsuk, S.; Jayaswal, R.K. McsA and the roles of metal binding motif in Staphylococcus aureus. FEMS Microbiol. Lett. 2012, 327, 126-133. [CrossRef] [PubMed]

66. Morgante, V.; Mirete, S.; de Figueras, C.G.; Cacho, M.P.; González-Pastor, J.E. Exploring the diversity of arsenic resistance genes from acid mine drainage microorganisms. Environ. Microbiol. 2015, 17, 1910-1925. [CrossRef]

67. Easton, J.A.; Thompson, P.; Crowder, M.W. Time-dependent translational response of E. coli to excess Zn(II). J. Biomol. Tech. 2006, 17, 303-307.

68. Ferianc, P.; Farewell, A.; Nystrom, T. The cadmium-stress stimulon of Escherichia coli K-12. Microbiology 1998, 144, 1045-1050. [CrossRef]

69. Babu, M.M.G.; Sridhar, J.; Gunasekaran, P. Global transcriptome analysis of Bacillus cereus ATCC 14579 in response to silver nitrate stress. J. Nanobiotechnol. 2011, 9, 49. [CrossRef]

70. Khan, A.L.; Ullah, I.; Hussain, J.; Kang, S.M.; Al-Harrasi, A.; Al-Rawahi, A.; Lee, I.J. Regulations of essential amino acids and proteomics of bacterial endophytes Sphingomonas sp. Lk11 during cadmium uptake. Environ. Toxicol. 2016, 31, 887-896. [CrossRef]

71. Siripornadulsil, S.; Thanwisai, L.; Siripornadulsil, W. Changes in the proteome of the cadmium-tolerant bacteria Cupriavidus taiwanensis KKU2500-3 in response to cadmium toxicity. Can. J. Microbiol. 2014, 60, 121-131. [CrossRef] [PubMed]

72. Hoffmann, A.; Bukau, B.; Kramer, G. Structure and function of the molecular chaperone Trigger Factor. Biochim. Biophys. Acta 2010, 1803, 650-661. [CrossRef] [PubMed]

73. Shah, S.; Damare, S. Differential protein expression in a marine-derived Staphylococcus sp. NIOSBK35 in response to arsenic(III). 3Biotech 2018, 8, 287. [CrossRef] [PubMed]

74. Lemire, J.A.; Harrison, J.J.; Turner, R.J. Antimicrobial activity of metals: Mechanisms, molecular targets and applications. Nat. Rev. Microbiol. 2013, 11,371-384. [CrossRef]

75. Liu, X.; Liu, H.; Wu, W.; Zhang, X.; Gu, T.; Zhu, M.; Tan, W. Oxidative stress induced by metal ions in bioleaching of $\mathrm{LiCoO}_{2}$ by an acidophilic microbial consortium. Front. Microbiol. 2020, 10, 3058. [CrossRef]

76. Ehrlich, H.L. Geomicrobiology, 3rd ed.; Marcel Dekker: New York, NY, USA, 1996.

77. Loenen, W.A. S-adenosylmethionine: Jack of all trades and master of everything? Biochem. Soc. Trans. 2006, 34, 330-333. [CrossRef]

78. Walker, J.; Gongora, R.; Vasquez, J.-J.; Drummelsmith, J.; Burchmore, R.; Roy, G.; Ouellette, M.; Gomez, M.A.; Saravia, N.G. Discovery of factors linked to antimony resistance in Leishmania panamensis through differential proteome analysis. Mol. Biochem. Parasitol. 2012, 183, 166-176. [CrossRef]

79. Dai, H.; Cao, F.; Chen, X.; Zhang, M.; Ahmed, I.M.; Chen, Z.-H.; Li, C.; Zhang, G.; Wu, F. Comparative proteomic analysis of aluminum tolerance in Tibetan wild and cultivated barleys. PLoS ONE 2013, 8, e63428. [CrossRef]

80. Hego, E.; Bes, C.M.; Bedon, F.; Palagi, P.M.; Chaumeil, P.; Barré, A.; Claverol, S.; Dupuy, J.-W.; Bonneu, M.; Lalanne, C.; et al. Differential accumulation of soluble proteins in roots of metallicolous and nonmetallicolous populations of Agrostis capillaris L. exposed to Cu. Proteomics 2014, 14, 1746-1758. [CrossRef]

81. Zhang, Y.; Lin, J.; Gao, Y. In silico identification of a multi-functional regulatory protein involved in Holliday junction resolution in bacteria. BMC Syst. Biol. 2012, 6, S20. [CrossRef]

82. Wei, L.; Wu, Y.; Qiao, H.; Xu, W.; Zhang, Y.; Liu, X.; Wang, Q. YebC controls virulence by activating T3SS gene expression in the pathogen Edwardsiella piscicida. FEMS Microbiol. Lett. 2018, 365, fny137. [CrossRef] [PubMed]

83. Wu, S.; Xia, X.; Wang, D.; Zhou, Z.; Wang, G. Gene function and expression regulation of RuvRCAB in bacterial Cr(VI), As(III), Sb(III), and Cd(II) resistance. Appl. Microbiol. Biotechnol. 2019, 103, 2701-2713. [CrossRef] [PubMed] 
84. Li, K.; Jiang, T.; Yu, B.; Wang, L.; Gao, C.; Ma, C.; Xu, P.; Ma., Y. Escherichia coli transcription termination factor NusA: Heat-induced oligomerization and chaperone activity. Sci. Rep. 2013, 3, 2347. [CrossRef] [PubMed]

85. Baker-Austin, C.; Dopson, M.; Wexler, M.; Sawers, R.G.; Stemmler, A.; Rosen, B.P.; Bond, P.L. Extreme arsenic resistance by the acidophilic archaeon 'Ferroplasma acidarmanus' Fer1. Extremophiles 2007, 11, 425-434. [CrossRef]

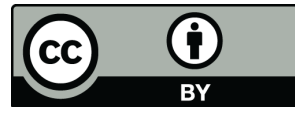

(C) 2020 by the authors. Licensee MDPI, Basel, Switzerland. This article is an open access article distributed under the terms and conditions of the Creative Commons Attribution (CC BY) license (http://creativecommons.org/licenses/by/4.0/). 